\title{
MANAGING FINANCIAL CONSTRAINTS: \\ UNDERCAPITALIZATION AND UNDERWRITING CAPACITY IN \\ SPANISH FIRE INSURANCE
}

Pablo Gutiérrez González

Research Assistant at the Department of Economics and Economic History

University of Seville

Spain

Lars-Fredrik Andersson

Associate Professor at the Department of Geography and Economic History

Umeå University

Sweden

\section{ABSTRACT}

Reinsurance is a vital financial device for enhancing underwriting capacity, ceding risks and mitigating financial distress. By supplying financial resources and services, reinsurance can facilitate growth and expansion in the insurance business. Focusing on the insurance sector in the emerging Spanish economy and using a novel dataset on fire insurance companies, this paper examines the role of fire insurance in the capital formation, the importance of reinsurance as a vehicle for expanding the country's domestic underwriting capacity, and how the capital import impacted on the balance of payment, from the introduction of the first comprehensive legislation regarding 
insurance in 1908 to the outbreak of the Civil War in 1936. Considering the situation of undercapitalization, the singularities of the insurance market, and the changes in regulatory schemes, we find that foreign reinsurance became a key financial vehicle for increasing the underwriting capacity in Spain. We also show the struggle for an emerging market to find ways to keep balance of current accounts and raise capital when the financial infrastructure is underdeveloped. The diffusion of reinsurance networks from the core of industrial Western countries towards emerging economies was one of the mechanisms for financial modernization on a global scale.

Technologies and devices developed in pioneering countries are expected to facilitate the performance of less developed economies. ${ }^{1}$ Latecomers benefit from the diffusion of knowledge from advanced economies, generating higher return and growth in the real economy. From a financial perspective, the advancement and expansion of financial services and instruments in pioneering countries can facilitate the diffusion of capital and knowledge for the development of banking and insurance in developing countries. ${ }^{2}$ Indeed, as shown by Pearson, continental Europe benefited from the insuring experience and new instruments that diffused from the United Kingdom in the nineteenth and early twentieth centuries. ${ }^{3}$ Nevertheless, the lower levels of capital accumulation and the fragmentation of the market forced continental insurers to develop new devices beyond those complex pools of risk diversification, such as Lloyd's of London, used by British

\footnotetext{
${ }^{1}$ Gerschenkron, Economic backwardness and Krugman, 'A model of innovation'.

2 Rousseau and Sylla, 'Financial System, Growth and Globalization'.

${ }^{3}$ Pearson, Insuring the industrial revolution.
} 
offices. German and Swiss insurers benefited from new management focuses, and dealt with capital constraints by employing innovative financial devices. ${ }^{4}$

From the mid-nineteenth century onwards, reinsurance was one of the growing global mechanisms of financial risk diversification. It became a key financial vehicle for enhancing underwriting capacity, ceding risks, and mitigating financial distress in Western economies. ${ }^{5}$ In its capacity as a supplier of financial resources and risk services across countries, reinsurance early on became a global business. ${ }^{6}$ During the phase of industrialization and later, the diffusion of global reinsurance networks met a growing need for direct insurers to reduce their exposure to unexpected losses following the growth of capital structures. ${ }^{7}$ Moreover, by using reinsurance as an alternative to equity capital or accumulating resources, direct insurers could underwrite more risks without jeopardizing their financial solvency. Thus, reinsurance serves as an imperfect substitute for equity capital. ${ }^{8}$

Indeed, reinsurance allows small companies and mutual societies to overcome their scarcity (or lack) of equity capital and to maximize their market share in terms of business performance. ${ }^{9}$ As a consequence, reinsurance serves as an alternative to traditional sources of funding. Supplying an additional financial vehicle, the importance of reinsurance is expected to grow in undercapitalized economies and/or during periods of economic growth when the demand for funding is rising. ${ }^{10}$ In this process, peripheral latecomers such as Spain seem to have been highly influenced by the diffusion of such

\footnotetext{
${ }_{5}^{4}$ James et al., The value of risk, 9-10.

${ }^{5}$ Pearson, 'Development of reinsurance', and Pearson, 'Birth pains'.

${ }^{6}$ Borscheid and Haueter (eds.), World Insurance, 45 , and James et al., The value of risk, 68.

${ }^{7}$ Idem, Golding, A history of reinsurance, and Gerathewohl, Reinsurance.

8 Mayers and Smith, 'Evidence from reinsurance market', Berger, Cummins and Tennyson, 'Reinsurance', Garven and Lamn-Tennant, 'The demand for reinsurance' and Powell and Somner, 'Internal versus external capital'.

${ }^{9}$ Prieto, El reaseguro: función económica, Gerathewohl, Reinsurance and Pearson, 'Development of reinsurance'.

${ }^{10}$ Pearson, Insuring the industrial revolution, Pearson, ‘United Kingdom' and Kader et al., 'Determinants of reinsurance'.
} 
techniques. In barely 40 years of development, the Spanish insurance market managed to ride out financial rigidities and capital shortages in such a way that, as the First World War drew near, it was able to cover not only domestic risks but also foreign ones. $^{11}$

Focusing on the insurance sector in the emerging Spanish economy, this paper examines the determinants of foreign reinsurance demand in the Spanish fire insurance market from the introduction of the first comprehensive legislation in 1908 to the outbreak of the Civil War in 1936. As in other lines such as marine and life insurance, the strong presence of foreign companies and the supply of reinsurance from abroad became key elements in providing insurance coverage for the emerging Spanish economy. ${ }^{12}$ However, unlike the marine insurance business, fire insurance showed a stable foreign presence over the whole period and was less affected by the shock of the First World War. ${ }^{13}$ In addition, the weight of fire line in the insurance industry was increasingly higher than marine. Figure 1 shows the size of traditional lines and the total weight of insurance over GDP, from 1912 to 1934: along with the economic growth of the 1920s, fire insurance almost multiplied by five the size of marine market at the end of the decade, being one of the main components in the contribution of the insurance industry to the Spanish economy. In relation to life insurance, fire line was characterized by a more competitive and dynamic business environment. ${ }^{14}$ Moreover, the risk structure of life business and the wide use of other actuarial devices as mortality tables made reinsurance less decisive for the management of the portfolio. In this scenario, fire business in Spain during this period experienced a fast and sustained

\footnotetext{
${ }^{11}$ Tortella et al., Historia del seguro.

${ }^{12}$ Contemporary authors noted this importance. For example, Cenamor, 'El seguro sobre la vida', xi, discussed the dependence of Spanish life insurers on foreign reinsurance as the only way to avoid to 'perish without remedy'.

${ }_{13}^{13}$ Pons, 'A history of insurance', $158-9$.

${ }^{14}$ Pons, 'Multinational enterprises'.
} 
growth affected by large and concentrated risk pools, which resulted in higher dependence on the supply of risk diversification services as reinsurance.

Figure 1. Premiums earned in the main traditional lines of the Spanish insurance market, (million Pesetas, 1928-year price level) (left axis) and weight of total insurance premiums over GDP, in \% (right axis), between 1912 and 1934.

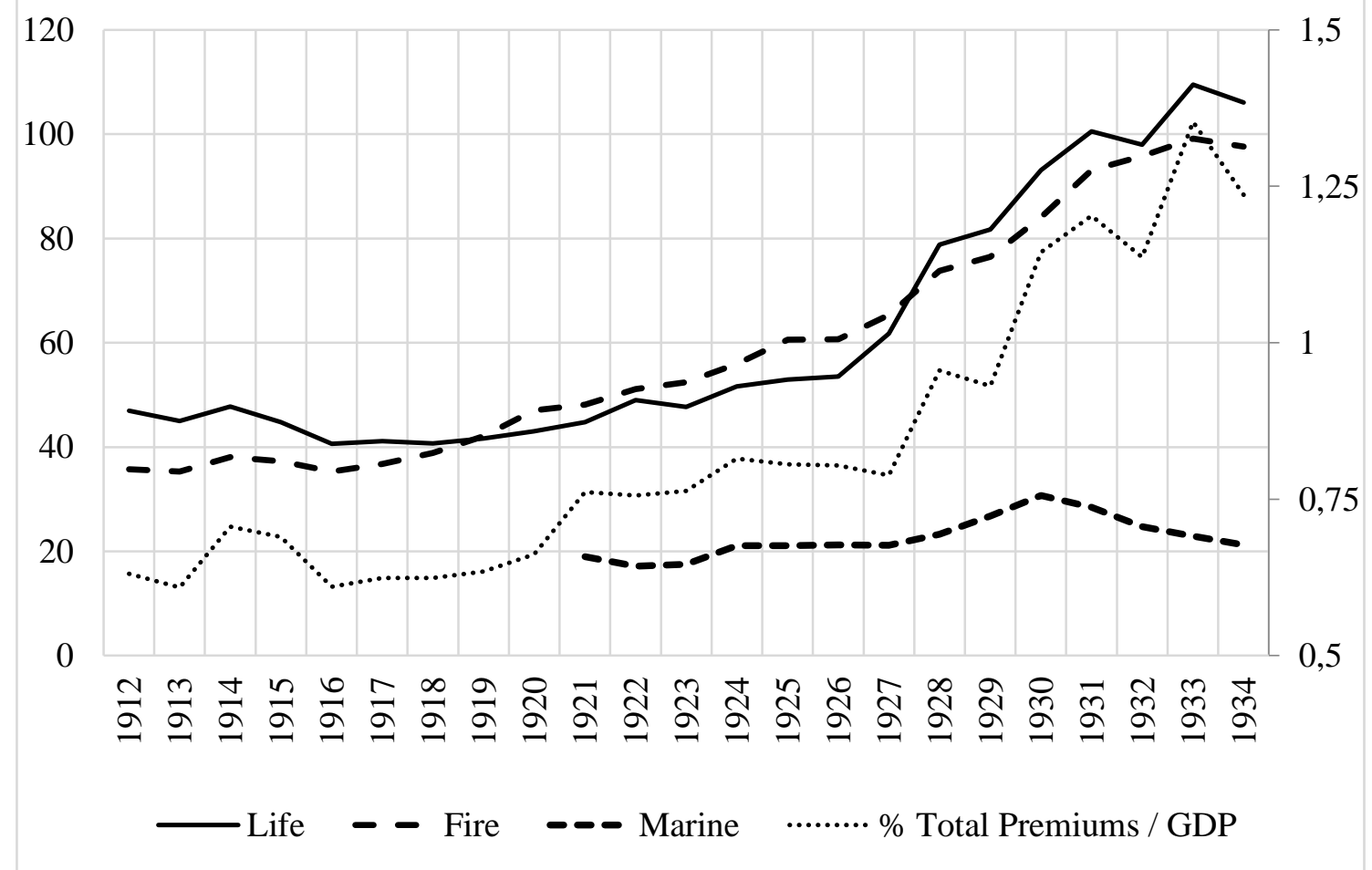

Note: Data on premiums earned by marine insurance companies are not available until 1920.

Sources: Pons, 'Estrategias de crecimiento', Appendix 1 and Carreras and Tafunell (eds.), Estadísticas Históricas de España, 1339.

The focus on the fire insurance business may be motivated by other reasons as well. As shown in previous studies, fire insurance played a vital role for emerging industrial economies by supplying both financial protection and indemnity of losses due to unexpected risks, and thereby mitigating the unanticipated risk of major financial losses associated with investment in physical capital. Also, by insuring one of the major collateral securities, fire insurance has been recognised for its importance in supporting an important part of the financial infrastructure of capital formation. ${ }^{15}$

\footnotetext{
${ }^{15}$ See e.g. Pearson, Insuring the industrial revolution.
} 
However, in meeting the demand from the emerging industrial economy, the Spanish fire insurance sector had to overcome a number of shortcomings. One of the major shortcomings was the shortage of capital in the domestic economy. Together with the singularities of the Spanish insurance market, and the changes in regulatory schemes, this paper argues that reinsurance became a vital financial vehicle for increasing the underwriting capacity in the undercapitalized Spanish insurance sector.

This paper will address the issue, placing the fire insurance industry into a wider context, and examining the determinants of reinsurance in line with the following three questions; (i) How did the expansion of fire insurance relate to capital formation in Spain? (ii) How did the use of reinsurance affect the strong dependency on foreign capital imports and, in the end, the performance of the Spanish balance of payments? (iii) Was there a systemic preference for purchasing reinsurance beyond firm-specific conditions affecting Spanish companies? To identify such conditions, we employ a novel and extensive dataset including both domestic Spanish fire insurance companies and foreign offices, for which we have categorized firm-specific and systemic preferences such as nationality.

The remainder of the paper is organized as follows. Section 2 traces the historical development of the Spanish financial and insurance sector from the late nineteenth century up to the late 1930s. Section 3 outlines the archival records, the data used for examining the role of reinsurance in the Spanish insurance sector, and descriptive statistics on fire insurance in Spain. Section 4 describes the empirical analysis and the key findings regarding the mechanisms underlying the role of reinsurance for Spanish insurers. Section 5 concludes the paper. 
The development of the Spanish insurance sector was slow in the nineteenth century. The demand for insurance was weak due to the unbalanced national growth trajectory, while political uncertainty and a restrictive legal framework presented obstacles for joint stock companies to supply insurance effectively. ${ }^{16}$ These difficulties resulted in the proliferation of mutual societies along traditional lines as fire and life during the central decades of the century. ${ }^{17}$ Most of the companies of this type were small local societies featured by the backwardness in managerial practices and a deep actuarial lag. ${ }^{18}$ Nevertheless, in the turbulent context of the 1860 s, a new legislation on stock companies was passed in $1869 .{ }^{19}$ Together with the political stability of the restored monarchy in 1875 , these changes improved the business environment in the latter part of the century. ${ }^{20}$ Far from being a drastic structural change, investments in productive assets resulted in a steady trend of growth in the capital stock. ${ }^{21}$ The increasing stock of buildings, machinery and transportation equipment triggered the demand for insurance coverage. Indeed, the growing needs of risk management devices made insurance a key element, supplying capital services to the manufacturing sector. ${ }^{22}$

Figure 2 shows the aggregated development of the capital stock (1878-1936) and the growth in the fire insurance business $(1908-1936) .{ }^{23}$ Dwellings, other buildings and infrastructures made up the major components of the stock of capital during the

\footnotetext{
${ }^{16}$ Frax and Matilla, 'Los seguros en España', 191-5, and Tortella et al., Historia del seguro, 88-90.

${ }^{17}$ Pons, 'International Influence', 190.

${ }^{18}$ Pons, 'A history of insurance', 146-8, 158. For more details about technical backwardness in the life branch, see Pons and Gutierrez, 'Actuarial practices', 11-6.

${ }_{19}$ Frax and Matilla, 'Los seguros en España', 187-8, and Pons, 'Multinational enterprises', 90, have underlined this change as the starting milestone for the insurance business in Spain

${ }^{20}$ Prados, El progreso económico, 230, points out the sustained growth before 1929, even though there were significant differences between the low rates until 1920 and the great expansion of the 1920s.

${ }^{21}$ Prados and Rosés, 'Capital accumulation', 162, determined an annual rate of growth of 2.3 per cent from 1883 to 1920 and 3.5 per cent from 1920 to 1929.

${ }^{22}$ A similar process for the Swedish case is described by Lilljegren and Andersson, 'Variation in organization', 79. According to Frax and Matilla, 'Los seguros en España', 193-4, number of companies in all lines increased from 32 in 1876 to 124 in 1908.

${ }^{23}$ There are no aggregated data previous to 1908 .
} 
whole period. Moreover, the expansion since the First World War and the price trends made both dwellings and buildings maintain and increase their weight beyond machinery and transportation equipment values.

Figure 2. Fixed-capital stock estimates by components (left axis), and fire insurance premiums (right axis), (million Pesetas, 1928-year price level) between 1876 and 1936.

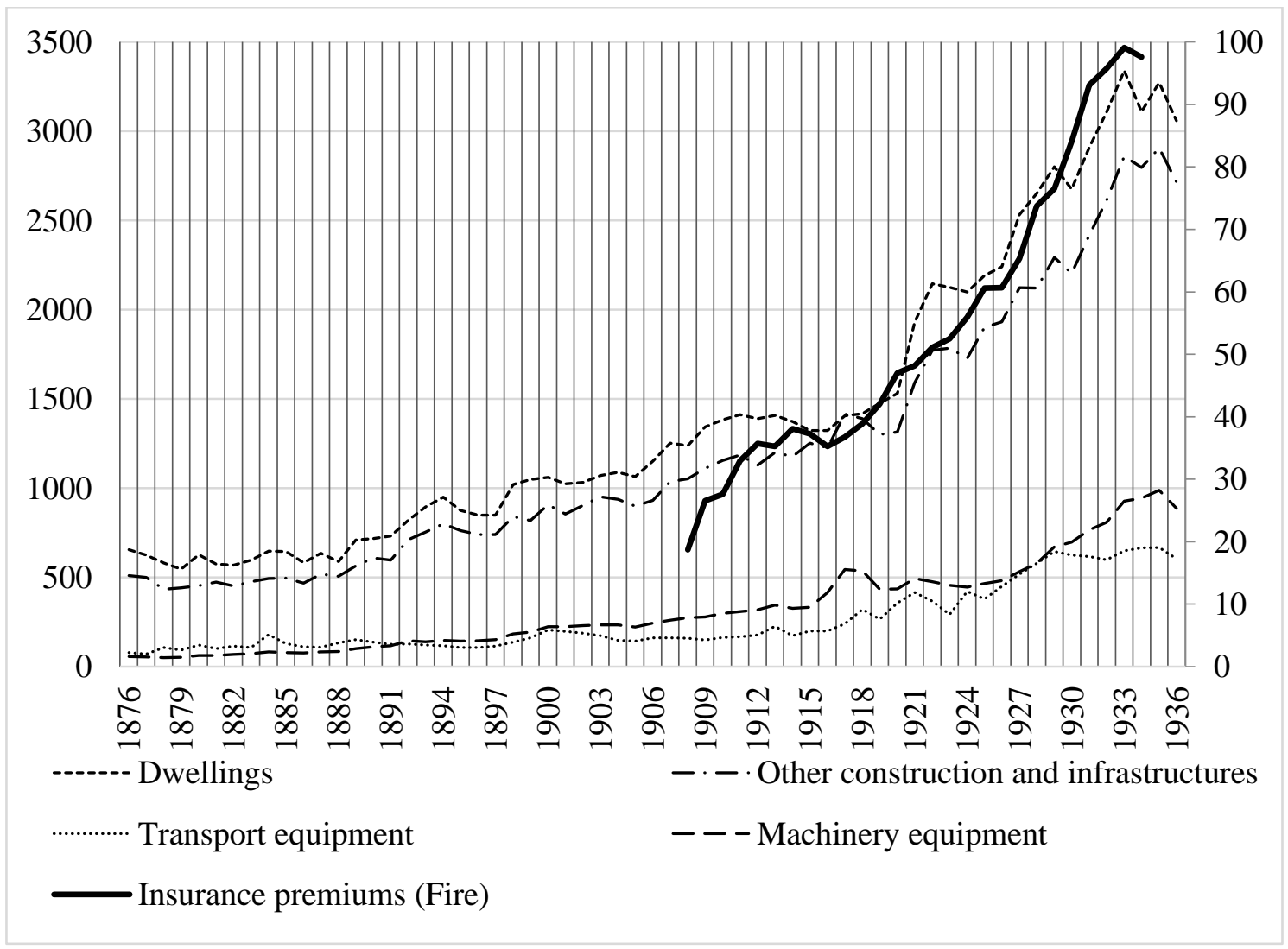

Sources: Prados and Rosés, 'Capital accumulation', Appendix Table A5, and Pons, 'Estrategias de crecimiento', Appendix 1.

The intense capital formation went hand-in-hand with the expansion of the fire insurance industry in Spain. From 1912 to 1932, the size of the market tripled in real terms. ${ }^{24}$ As shown in Figure 2, fire insurance kept pace with the growth of the capital stock with the exception for the years during the First World War.

This period of sustained growth coincided with a steady trend in internationalization. In the wake of the global expansion of financial business, several

\footnotetext{
${ }^{24}$ Pons, 'Diversificación y cartelización', 570.
} 
foreign and domestic insurance companies expanded into the emerging Spanish economy. Foreign offices coming from mature markets such as the United Kingdom and France supplied a substantial part of insurance coverage in Spain. ${ }^{25}$ Before the First World War, in 1912, the fire insurance market was shared between 16 domestic companies and 29 foreign offices. The foreign business share was $37 \% .^{26}$ The strong foreign presence resulted in the profuse adoption of innovative devices and practices from abroad: collusive practices in the way of the British Fire Offices Committee were employed around the Comité Español de Aseguradores de Incendios, which thus helped both domestic and foreign companies to set standard practices in the market. ${ }^{27}$ In parallel, French and British societies introduced the use of reinsurance into the Spanish insurance industry: in a first step as a way to enter the market; after that, as a mean of diversifying their portfolios. ${ }^{28}$

Together with this openness and the increasing size of the market, the economy concealed internal imbalances and systemic shortcomings that hindered the development of the domestic insurance industry and paved the way for the entrance of foreign offices. Certainly, despite the rates of growth experienced since 1875, the Spanish financial system remained underdeveloped at the turn of the century. ${ }^{29}$ Based on the five basic characteristics of a successful financial system according to Rousseau and Sylla, Spain suffered from a number of structural shortcomings. ${ }^{30}$ Indeed, with

\footnotetext{
${ }^{25}$ Pons, 'Estrategias de crecimiento', 12, and 'Influence of foreign companies', Pearson, Insuring the industrial revolution, Alborn, Regulated lives and Wilkins, 'Multinational enterprise'.

${ }^{26}$ Pons, 'Influence of foreign companies', 51. Foreign insurers were registered as branch offices of their mother company. They did not declare equity capital, and their only financial support against liabilities in Spain were their accumulated reserves, although head offices were expected to back their operations.

${ }^{27}$ Pons, 'Las empresas extranjeras', 200. Pons, 'Diversificación y cartelización', 584-5, also describes the Comité Central de Compañías de Seguros contra Incendios as a precedent in the nineteenth century.

${ }^{28}$ Pearson, 'Las compañías de seguros extranjeras', 116-8.

${ }^{29}$ Malo de Molina and Martín-Aceña, 'Introduction', 4-5, and Pons, 'The main reforms', 73-6.

${ }^{30}$ Rousseau and Sylla, 'Financial System, Growth and Globalization', 374-7. These features are presented as follows: (1) public finance, including its debt management, is run prudently; (2) a stable currency; (3) private commercial banks involved in international and/or domestic financial business; (4) monetary authority that can act to stabilize domestic finances and manage international financial relations, and (5) a well-functioning securities market.
} 
regard to 1) public finance and 2) a stable currency, the country's persistent public deficit and non-adhesion to the Gold Standard caused monetary policy to be subordinated to fiscal needs, which determined the role of the Bank of Spain. ${ }^{31}$ Regarding 3) private banking, the central bank was crucial in stabilizing domestic finances, but it is also true that its excessive dominance of the whole financial system posed obstacles to the internationalization of the banking industry; 4) a monetary authority). ${ }^{32}$ Finally, in relation to 5), a securities market), like other continental European countries, the Spanish securities market was connected more to public debt than to industrial capital formation, which resulted in a relatively low profile in quantitative terms. ${ }^{33}$

Table 1. Financial assets as a percentage of GDP.

\begin{tabular}{lcccc}
\hline & 1900 & 1913 & 1929 & 1938 \\
\cline { 2 - 5 } United Kingdom & 93 & 103 & 131 & 158 \\
France & 96 & 104 & 90 & 130 \\
Germany & 114 & 158 & 89 & 99 \\
Italy & 61 & 97 & 95 & 137 \\
Spain & 37 & 35 & 74 & 81 \\
\hline
\end{tabular}

Source: Carreras and Tafunell (eds.), Estadísticas históricas de España, 651.

Table 1 shows the composition financial activities over the Spanish economy compared to the main European markets. The face values of the country's financial assets were under $40 \%$ of its GDP until the First World War, while they were close to $100 \%$ or more in countries like the UK, France, Germany, and Italy. It was not until the 1920s that the Spanish financial industry began to converge with those of developed countries. One of the main components of the system, the banking business, was characterized by extreme regionalization, a lack of diversification, and the excessive

\footnotetext{
${ }^{31}$ Comín, 'Las crisis de la deuda', 206-7 and Martínez Ruiz, 'Papel mojado. Crisis inflacionarias'.

${ }^{32}$ Martín-Aceña, 'Spain during Gold Standard', 'Crisis bancarias', and 'The Spanish banking system', 99-103.

${ }^{33}$ Total capital traded in Madrid stock exchange was below 10\% of GDP until well into the 1980s. Cuevas, 'Las crisis bursátiles', 162-5.
} 
dominance of the Bank of Spain. These elements defined a financial system characterized by the predominance of commercial banking over other services. ${ }^{34}$ In the case of insurance, rigidities in the capital markets developed, with low requirements on capital ratios for Spanish societies and an absence of obstacles to the establishment of foreign companies until 1893. Consequently, the domestic insurance industry was negatively affected by a lack of capital resources and a high firm mortality ratio. ${ }^{35}$

In addition to the limitations of the financial system, the Spanish foreign sector suffered from a weak international position that resulted in persistent deficits of the current account after the middle of the nineteenth century. ${ }^{36}$ Especially in the case of services balance, there were only four annual surpluses from 1850 to 1913 , while net capital inflows declined around the turn of the century. ${ }^{37}$ The extension of this trend throughout the next decades deeply affected those industries showing a high presence of foreign capital, as was the case of insurance. Moreover, the deterioration of trade and the slowdown of the entries of foreign capital deeply affected the position of the Spanish currency. In 1883, the Bank of Spain suspended the gold convertibility of the peseta, commencing a half-century period in which it performed as a fiat currency at the periphery of the gold standard Europe. ${ }^{38}$ Indeed, the changing performance of the domestic currency posed several difficulties for the access of Spanish companies to the international capital markets.

\footnotetext{
${ }^{34}$ Martín-Aceña, 'Desarrollo y modernización'.

${ }^{35}$ Tortella et al., Historia del seguro, 112-3 and Pons, 'Estrategias de crecimiento', 14. Pons underlines this high mortality ratio as characteristic of the companies established in regional areas in the last decades of the century.

36 According to Prados, 'Spain's International Position', 190, only from 1890 was there a relatively prolonged period of surplus balances, although this trend was broken by the deficits in the period 1900-4. ${ }^{37}$ Idem, 191.

${ }^{38}$ See Appendix A.3. For a comparison of the performance of the peseta and the pound sterling in this period, see Gadea and Sabaté, 'The European Periphery', 64.
} 
Figure 3. Aggregated premium income in fire insurance and estimates of service imports in fire insurance (million Pesetas, 1928-years price level) in Spain between 1908 and 1934.

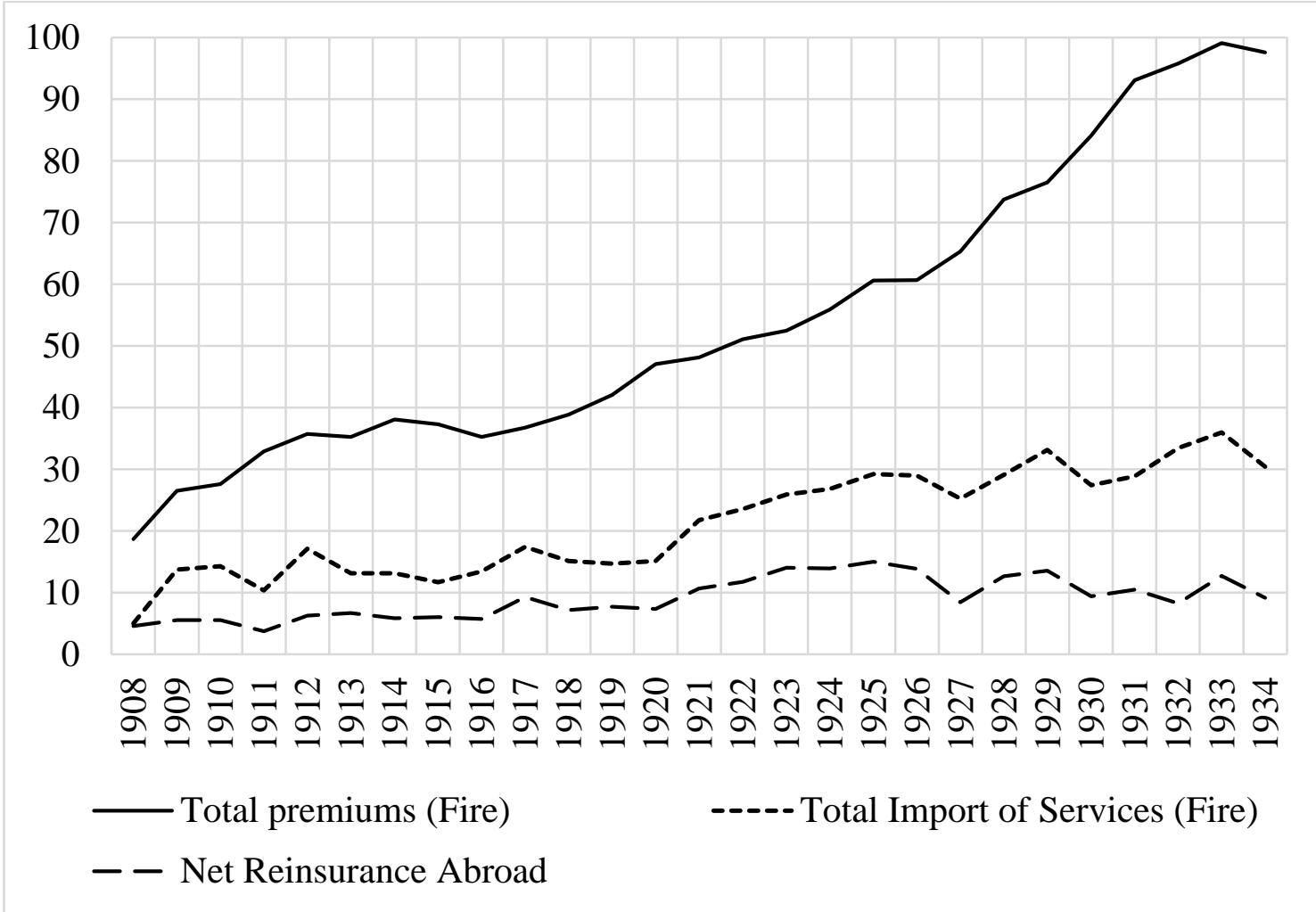

Note: Estimates on imports of services are calculated as the sum of two components: 1) Direct import by branches of foreign companies = Premiums earned by branches of foreign companies in Spain - Claims paid; and 2) Net reinsurance abroad = Premiums reinsured abroad by domestic companies - Claims covered by reinsurance. Due to the lack of data on retrocessions, all reinsurance purchased by domestic companies is assumed to be reinsured abroad.

Sources: Pons, 'Estrategias de crecimiento', Appendix 1, and AGA (1) 26 - Cajas I-1 to I-141 Top. 13/31 and AGA (1) 26 - Cajas 11/02131 to 11/02180; Comisaría General de Seguros, Memoria sobre las entidades de seguros que operan en España, Years 1911, 1912, 1913, 1915.

Figure 3 shows the estimates on imports of insurance services including net reinsurance purchases by Spanish companies and gross premium income in the fire branch from 1908 to $1935 .{ }^{39}$ Service imports remained as a key component of fire insurance, though its importance on the business came to a standstill after the implementation of the 1908 Act. After First World War turbulences, the global

\footnotetext{
39 Following the System of National Accounting 2008, insurance and reinsurance transactions are recorded in the balance of payments as imports or exports of services. Figure 3 shows a simplified approach excluding the net change in reserves, service charges and the adjustment for the volatility of claims.
} 
environment and the hardening of economic nationalism exacerbated this trend and led to the disengagement of foreign companies, especially after 1925 . In the same period, net reinsurance premiums ceded by Spanish companies remained as a major component, providing additional insurance coverage to the fire business: from 1908 to 1930, net reinsurance premiums averaged around 20 per cent of total premium income in the fire line. While this capital outflow served to enhance the underwriting capacity of Spanish insurers, it also exacerbated the Spanish balance of payments deficit. ${ }^{40}$

In addition to the structural features of the Spanish economy, the insurance industry had to face deep institutional changes inspired by the trends of economic nationalism. The 1908 Act on Registry and Inscription of insurance companies imposed a new legal framework establishing a strict supervision of insurance companies and creating an official registry of authorized insurers. To be authorized to sell policies, companies were to report their operations to the regulatory agency and comply with the requirements concerning reserves and equity capital established in the legislation. In practice, the new rules directly affected foreign offices since the obligation to maintain their reserves deposited in Spain posed increasing difficulties to their performance. ${ }^{41}$ In line with trends in economic nationalism, domestic companies required more public control of the operations of foreign insurers, in order to occupy their market share and to avoid the outflow of national wealth. ${ }^{42}$ Moreover, the actual nationality of several companies registered as Spanish but totally or partially owned by foreign capital became a controversial issue, making frequent the appeals for more rigorous

\footnotetext{
${ }^{40}$ The Bank of Spain's Studies Service noted this performance in the analysis of the balance of payments for 1931: in spite of the difficulties for measuring reinsurance operations, the Service calculated a net outflow abroad of more than five million pesetas. Gutiérrez and Pons, 'Risk management', 8.

${ }^{41}$ Pons, 'Estrategias de crecimiento', Pons, 'Influence of foreign companies', Pons, 'Multinational enterprises' and Pearson, 'Growth, organization and diffusion'. Among foreign companies, those operating in the fire branch were the most affected. Marine insurance was exempt from the 1908 Inspection and Registry Act, while life companies had already formed high mathematical reserves in the previous decades.

${ }^{42}$ Pons, 'Las empresas extranjeras', 202-3.
} 
requirements on nationality classification to avoid the proliferation of false Spanish insurers. $^{43}$

In this scenario, the increasing pressure of the legislation converged with an external shock. The outbreak of the First World War and its effects on the international market placed Spanish companies between the main suppliers of marine freight and insurance. ${ }^{44}$ Many small and undercapitalized companies were established to insure and reinsure these risks. Likewise, the great growth of the marine insurance market attracted several offices from other lines such as fire. However, the buoyancy of the industry was eroded by financial distress. As a consequence, direct insurers resorted profusely to foreign reinsurance. The increasing outflows of capital caught the attention of the government, which reacted by limiting the reinsurance ratios and forcing the companies to cede part of their risks to the Official Committee on War Insurance, a state-dependent authority, in order to stop what was seen as the drain of national wealth. ${ }^{45}$

In Spain, the fragmentation of the international market due to the war and the monetary disruptions until 1923 coincided with a post-war crisis, emerging in the insurance industry in the form of the liquidation of many small marine and fire insurers and reinsurers. ${ }^{46}$ This led to a tightening of the legislation and an increase in financial requirements, such as the imposition of the requirements of the 1908 Act on the marine branch, and the requirement to invest long-term reserves in Spanish securities. ${ }^{47}$ Moreover, the increase on the minimum deposits and equity capital required for different lines and the stricter limitations on the investment of the reserves led several

\footnotetext{
43 Spanish companies formed in 1928 the Federación de Compañías Españolas de Seguros, an association inspired by La Equitativa Group to lobby for stricter regulations for foreign companies. For more details, see Tortella et al., Historia del seguro, 147-9.

${ }^{44}$ For further explanation of the impact of the war on the Spanish economy, see Sudriá, 'Los beneficios de España' and San Román, 'Las consecuencias pacíficas'. For an analysis of the effects on insurance markets, see Gutiérrez, El control de divisas.

45 Canals, Cuestiones económicas, Gutiérrez, El control de divisas and Gutiérrez and Pons, 'Risk management'.

${ }^{46}$ Tortella et al., Historia del seguro and Gutiérrez and Pons, 'Risk management', 5-6.

${ }^{47}$ Royal Decree of 13 August of 1920, Gaceta de Madrid no. 228, 15/08/1920.
} 
foreign insurance companies to reduce their operations or even abandon the market, especially during 1933 and $1934 .^{48}$

Despite the financial obstacles, the Spanish insurance sector expanded across all lines in the 1920s. In the line of fire, business grew by almost $50 \%$ in real terms from 1920 to $1927 .{ }^{49}$ The expansion took off during the culmination of the process of cartelization among joint stock companies with the constitution of the Sindicato General de Compañias de Seguros contra Incendios in $1924 .{ }^{50}$ In addition, the Spanish insurance industry was affected to a lesser extent by the global depression; the low levels of internationalization of the Spanish economy contributed to minimizing the impact of the crisis. ${ }^{51}$ In the case of the insurance market, the life insurance industry was the most exposed to the financial volatility, but despite this, companies continued growing until $1936 .^{52}$

Nevertheless, this period of growth and development did not end with the main imbalances inherited from the nineteenth century. The number of companies underwriting business on the fire insurance market almost doubled between 1912 and 1932, and the mean premiums earned by companies grew by some $80 \%$ in real terms during the same period. ${ }^{53}$ Thus, domestic companies underwriting on the growing Spanish fire insurance market increased their liabilities and leverage between 1908 and 1936. Unless they had external support, one would have expected that their financial position would have declined, making the probability of bankruptcy higher. From a ruin

\footnotetext{
${ }^{48}$ Pons, 'Las carteras de valores', Pearson, 'Growth, organization and diffusion' and Pons and Gutiérrez, 'Actuarial practices'. The Royal Decree of 18 February of 1927, Gaceta de Madrid no. 50, 19/02/1927, raised the minimum equity capital to operate in fire branch at 2 million pesetas, with a minimum guarantee deposit of $25 \%$. Finally, the sound protest of foreign companies resulted in the application of these new conditions only to those offices registered after the entrance in force of the Royal Decree. Pons, 'Multinational enterprises', 108.

${ }^{49}$ Pons, 'Estrategias de crecimiento', 119.

${ }^{50}$ Pons, 'Influence of foreign companies'.

${ }^{51}$ Bartolomé, Martín-Aceña and Martínez Ruiz, 'A Spanish tale'.

${ }_{53}^{52}$ Pons, 'Estrategias de crecimiento', and Tortella et al., Historia del seguro.

${ }^{53}$ Pons, 'Estrategias de crecimiento', 43-4.
} 
theory framework, managers would have had to decide between three approaches in order to reduce or keep stable this probability of ruin: (1) improve the performance of the portfolio, (2) accumulate capital, or (3) purchase reinsurance. ${ }^{54}$ In the first case, managers could increase the net surplus of the portfolio either by raising the price of insurance or by increasing low-variance risk contracts. Such a strategy, however, seems less likely in a competitive market such as the Spanish one in the period of study. It also seems less likely that companies were able to increase the number of low-variance risk contracts, which even in the case of avoiding reducing prices would be difficult since, according to Deelstra and Plantin, such risks are the most inelastic part of the market. In the second option, increasing capital could be a difficult task for Spanish insurance companies during this period. Though the financial system had progressed since 1900, a lack of diversification or specialization and business instability remained, as did the problems of the banking industry, which continued to be the main component of the financial system. ${ }^{55}$ These elements obstructed the capitalization of the Spanish insurance industry. Indeed, immediately before the outbreak of the Spanish Civil War, the insurance industry showed shortages of capital that resulted in extraordinarily high levels of leverage ${ }^{56}$ Faced with an undercapitalized financial market and a high level of liabilities, reinsurance seem to have been more attractive to domestic insurers than foreign companies on the expanding Spanish fire insurance market.

In order to determine whether such a preference was predominant among Spanish insurance companies or the outcome of the Spanish insurance market in general, the following analysis will focus on the determinants of reinsurance. The

\footnotetext{
${ }^{54}$ Doherty and Tinic, 'Reinsurance under equilibrium', Plantin and Rochet, When insurers go bust and Deelstra and Plantin, Risk theory and reinsurance, 27-8.

${ }_{55}^{5}$ Malo de Molina and Martín-Aceña, The Spanish Financial System.

${ }^{56} \mathrm{The} \mathrm{P} / \mathrm{S}$ ratio (premiums earned over surplus) is widely accepted as a valid indicator of leverage. The sample of fire insurers used in Kader et al., 'Determinants of reinsurance' in the case of Sweden between 1919 and 1939, shows mean values for the P/S ratio of 0.410. Using official aggregate data from the Dirección General de Seguros for 1942, Gutiérrez, El control de divisas, 48, displays a value for Spain of 1.741 .
} 
analysis aims at identifying whether there was a systemic preference for purchasing reinsurance based on the country of origin (nationality), or whether reinsurance purchase was the outcome of firm-specific conditions.

\section{II}

There are no complete published or edited official statistical series on Spanish reinsurance until 1942. The available data for the insurance industry as a whole are the annual reports in the Boletín Oficial de Seguros, Boletín Oficial de la Inspección Mercantil y Boletín Oficial de Seguros y Ahorro, which include the premiums underwritten from 1911 to 1935. Edited information on the premiums reinsured, reserves, claims experience, liquidity indicators, and other financial data are only available for a few years. ${ }^{57}$ To overcome this lack of statistics, we have collected the financial balances sent by companies to the regulation agency after 1908 and currently located at the Archivo General de la Administracion (AGA). ${ }^{58}$ These include the main accounting sheets of the companies: statements of financial positions and profit and loss accounts. From these documents we have collected the premiums earned, claims paid, reinsured premiums, cash and liquid assets in bank accounts, equity capital declared, and ongoing-risks reserves.

Between 1908 and 1936, there were 117 companies authorized to underwrite fire insurance policies in Spain. However, only a third of them operated throughout the period without interruption. New entrances and exits from the fire branch as well as liquidation processes determined a highly changing scenario in which the total number

\footnotetext{
${ }^{57}$ Comisaría General de Seguros, Memoria sobre las entidades de seguros que operan en España, 1911, 1912, 1913, 1915.

58 AGA (1) 26 - Cajas I1 to I-141 Top. 13/31 and AGA (1) 26 - Cajas 11/02131 to 11/02180. The obligation to report their operations was established within the legal framework of the 1908 Inspection and Registry Act. Although there are companies reporting after 1908, the standard model of report was not defined until 1912.
} 
of companies registered for each year varied between 46 in 1912 and 79 in 1934. Besides this volatility, there is a great deal of missing data due to different reasons: many offices sent incomplete information on their operations; some diversified companies reported mixed data from various branches; and, finally, insurers authorized to underwrite fire business that were retreating from the branch, or even not selling policies, showed abnormally low values for main indicators. Consequently, those entries showing a large amount of missing and/or extreme data have been excluded from the dataset.

Our full sample includes 62 insurers distributed along the period 1908-1934 and fluctuating from 41 in 1915 to 33 companies in 1931. The years before 1910 and after 1932 show a clear lack of data from fire insurers, with fewer than 15 companies reporting their operations, so these have been analysed separately. As a result, compared to the data from Pons, our dataset includes between $80 \%$ (in 1912) and $45 \%$ (in 1931) of total companies authorized for each year. ${ }^{59}$ However, in terms of market share, the sample represents no less than $85 \%$ of total premiums earned (as we have excluded most local companies and small mutual societies with less than $1 \%$ of market share). ${ }^{60}$ Regarding the nationality of the companies, the sample includes 27 Spanish, 15 British, ten French, three Swiss, three German companies, and one each from the United States, Italy, Denmark, and Portugal. ${ }^{61}$ Among the Spanish companies, we include only three mutual societies; despite the number of this kind of society in the Spanish fire branch, most of them operated within a local scope and underwrote only minor amounts of business.

\footnotetext{
${ }^{59}$ Pons, 'Estrategias de crecimiento', Appendix 3.

${ }^{60}$ For example, Pons, 'Estrategias de crecimiento', estimates total fire insurance premiums earned in Spain in 1930 at 76.5 million Pesetas, while our sample reaches 73.4 million.

${ }^{61}$ As shown in the first section, the actual nationality of companies was a controversial issue in this period. This sample includes three companies with a significant presence of foreign capital: La Unión y el Fénix Español, Hispania and Numancia.
} 
Table 2 includes the main descriptive statistics (mean and standard deviation) for the key variables built from the data collected. Our dependent variable, reinsurance (REIN), is expressed as the percentage of reinsured premiums over the total amount of premiums earned. With regard to our independent variables, the previous literature has stated a positive relation between leverage and the probability of ruin, which, in turn, connects it positively with reinsurance. ${ }^{62}$ Though the premium to surplus ratio (P/S) has frequently been used as an indicator of leverage in the literature, it shows several limitations in our sample. ${ }^{63}$ Several Spanish stock companies showed differences up to $70 \%$ between equity capitals declared and effectively deposited. Mutual societies add further heterogeneity, since they have no equity capital. Foreign offices did not declare equity capital in Spain because, according to insurance regulations, they received financial support from their headquarters. ${ }^{64}$ Searching for a homogeneous indicator, we seek a variable expressing the available resources allocated by the company to face the liabilities resulting from policies in force. Therefore, we have chosen the ongoing-risks reserves as a variable common to all kinds of insurers and one that is only subjected to managerial decisions, unlike other statistics strictly marked by legal obligations.

The Registry Act of 1908 established the minimum amount of ongoing risk reserves as one third of written premiums, and the lack of control until the end of each exercise let many companies operate during most of the year under this limit, while others decided to form larger reserves, always depending on the office strategy. ${ }^{65}$

\footnotetext{
${ }^{62}$ Mayers and Smith, 'Corporate demand for insurance' and Mayers and Smith, 'Evidence from reinsurance market'.

${ }^{63} \mathrm{P} / \mathrm{S}$ ratio is defined as net premiums written over total surplus. Idem, Cole and McCullough, 'A reexamination of the corporate demand' and Kader et al., 'Determinants of reinsurance' used the sum of equity and reserves as surplus value.

${ }^{64}$ After several controversies on the issue, the Royal Order of 1st of April of 1913 obliged foreign insurers to declare as equity capital the amount corresponding to their head offices. Actually, these sums were not deposited in Spain nor they were subjected to Spanish legislation.

${ }^{65}$ See Regulation on the implementation of the Registry Act of 1908, of February 2nd of 1912, in Gaceta de Madrid 49, 18/02/1912. The firms in our sample show that the average leverage was too high to meet these legal requirements: ongoing risk reserves made up only $25.4 \%$ on the written premiums.
} 
Consequently, our variable acts as an indicator of the solvency risk of the company and as a proxy for partial leverage (LEV), since it is confronting the total business written by the insurer to the amount of resources that the managers are willing to tie up in order to face eventual liabilities. ${ }^{66} \mathrm{LEV}$ is calculated as the percentage of total premiums earned over ongoing-risks reserves.

Given that reinsurance serves to reduce the exposure to unexpected claims, previous authors have considered loss ratio to be closely and positively related to reinsurance purchases. ${ }^{67}$ In line with this, we use loss ratio (LOSS), expressed as the percentage of total claims paid over premiums earned. Plantin argues that insurers with fewer liquid assets available are expected to purchase more reinsurance in order to overcome their cash-resources constraints. ${ }^{68}$ In our research, liquidity (LIQ) is equal to the percentage of total liquid assets (cash and bank accounts) over current liabilities, expressed as ongoing reserves. According to the previous literature, size is expected to be negatively related to reinsurance, since small companies are more sensitive to losses. ${ }^{69}$ We express size (SIZE) as the natural logarithm of total business underwritten. Finally, older companies are expected to have a wider knowledge of the market and to be more efficient. ${ }^{70}$ In the case of insurance, this experience would appear as a lower loss volatility in the risk portfolio; thus, age would be negatively related to reinsurance. In this research, age (AGE) is expressed as the total years of operation of the company on the Spanish insurance market.

\footnotetext{
${ }^{66}$ As shown by Pons, 'Las entidades aseguradoras', 345-6, these reserves should be formed with cash resources and low yield securities as Spanish State bonds, public securities from foreign states with rates of return lower than $4 \%$, corporate debt securities and bonds traded in Spanish stock market but only if they maintained the $75 \%$ of their nominal value, and mortgage bonds, which could not exceed $25 \%$ of the overall reserves value.

${ }^{67}$ Mayers and Smith, 'Evidence from reinsurance market' and Lamn-Tennant and Starks, 'Stock versus mutual'.

${ }^{68}$ Plantin, 'Does reinsurance need reinsurers?'.

${ }^{69}$ Adams, 'The reinsurance decision' and Adiel, 'Reinsurance'.

${ }^{70}$ Jovanovic, 'Selection'.
} 
Table 2. Fire insurance companies in Spain (1908-1934). Descriptive statistics for firmspecific variables by nationality and organizational form. Mean and (standard deviation).

\begin{tabular}{|c|c|c|c|c|c|c|c|}
\hline \multirow{2}{*}{\multicolumn{2}{|c|}{ Sign }} & \multirow{2}{*}{$\begin{array}{c}\text { Full } \\
\text { Sample }\end{array}$} & \multicolumn{2}{|c|}{ Spanish } & \multirow{2}{*}{ British } & \multirow{2}{*}{ French } & \multirow{2}{*}{ Other } \\
\hline & & & All & Mutual & & & \\
\hline \multirow{2}{*}{ REIN } & & 30.21 & 41.68 & 82.87 & & 25.77 & 41.52 \\
\hline & & (24.72) & (24.03) & $(6.21)$ & (16. & (18.4 & (32.66) \\
\hline \multirow{2}{*}{ LEV } & & 392.77 & 442.34 & 650.23 & 350 & 358.62 & 414.12 \\
\hline & + & (202.12) & (249.88) & (121.29) & (131 & $(158$. & $(227.32)$ \\
\hline \multirow{2}{*}{ LOSS } & & 35.62 & 31.36 & 28.64 & 44.65 & 34.52 & 27.50 \\
\hline & + & (25.26) & (18.61) & (27.38) & (32.95) & (20.12) & $(22.75)$ \\
\hline \multirow{2}{*}{ LIQ } & - & 114.57 & 121.35 & 64.35 & 120.85 & 52.84 & 185.32 \\
\hline & - & $(332.40)$ & (134.50) & $(34.81)$ & $(493.28)$ & $(72.86)$ & $(466.20)$ \\
\hline \multirow{2}{*}{ SIZE } & & 12.30 & 12.71 & 12.16 & 12.17 & 12.41 & 11.26 \\
\hline & - & $(1.47)$ & $(1.71)$ & $(0.36)$ & & $(1.42)$ & (1.14) \\
\hline \multirow{2}{*}{ AGE } & - & 30.07 & 25.56 & 20.58 & 36.65 & 33.16 & 18.89 \\
\hline & - & (20.03) & (18.18) & $(8.31)$ & (24.10) & (14.80) & (14.98) \\
\hline \multicolumn{2}{|c|}{ No. of firms } & 62 & 27 & 3 & 15 & 10 & 10 \\
\hline
\end{tabular}

Note: REIN $=$ Premiums reinsured / Premiums earned, in \%; LEV $=$ Premiums earned / Ongoing-risks reserves, in \%; LOSS $=$ Claims $/$ Premiums earned, in \%; LIQ $=$ Cash + Bank accounts / Ongoing-risks reserves, in \%; SIZE = Natural logarithm of premiums earned; $A G E=n^{\circ}$ of years since the first registration in fire branch in Spain.

Source: AGA (1) 26 - Cajas I-1 to I-141 Top. 13/31 and AGA (1) 26 - Cajas 11/02131 to 11/02180; Comisaría General de Seguros, Memoria sobre las entidades de seguros que operan en España, Years 1911, 1912, 1913, 1915.

To examine whether reinsurance purchases go beyond that of firm-specific characteristics, we have employed nationality as a proxy identifying systematic preference. We classify our sample according to nationality (Spanish, British, French, and Other), given that we suppose a greater inclination to purchase reinsurance for domestic companies facing more of the structural shortcomings of the Spanish financial system. Given that foreign companies were integrated into their home country's capital markets, we expect a lower need for reinsurance to overcome financial system shortcomings. 
To identify a preference of reinsurance based on organizational form, we have separated mutual societies from joint-stock companies, since previous literature states that organizational form has a deep influence on the performance of the risk portfolio. ${ }^{71}$ According to this, we expect mutual societies to demand more reinsurance than do stock companies, as they suffered from capital constraints derived from their lack of equity capital.

Finally, for country-level control variables we consider two macroeconomic indicators that are expected to affect reinsurance demand. First, we use the GDP real growth (GRTH) from Carreras and Tafunell, Estadísticas históricas, since economic growth is expected to increase insurance covering demand, which, in turn, would positively affect reinsurance services. ${ }^{72}$ Second, we use the Peseta/French Franc (FF) exchange rate in order to measure the monetary effect on the demand for foreign reinsurance. Thus, we consider that the lower/higher rate of exchange would improve/worsen the position of Spanish insurers in order to purchase foreign reinsurance, which would result in higher/lower reinsurance ratios. Between official exchange rates, we use the French Franc not only because of the close links with the French market but also for its better performance compared to the British Pound, with respect to other macro indicators such as inflation and legal interest rates.

As shown in Table 2, the mean reinsured portion of risks in the Spanish fire insurance industry reached almost $30 \%$ of the business. However, looking at the standard deviation, there were substantial differences within the sector. Organizing the data according to nationality it can be seen that, as we expected, Spanish companies purchased more reinsurance than did British or French ones. Certainly, these offices

\footnotetext{
71 Prieto, El reaseguro: función económica, Pearson, 'Development of reinsurance', Adams, 'The reinsurance decision' and Kader et al., 'Determinants of reinsurance'.

${ }^{72}$ We use GDP data at market prices and the main price index, both by Prados de la Escosura, in Carreras and Tafunell, Estadísticas históricas, 1291; 1331.
} 
would have access to the financial support of their mother companies, which in turn had direct contact with more capitalized financial markets. Leverage shows a similar trend, with Spanish companies reaching higher values than British and French ones, and mutual societies surpassing the rest.

Companies from other countries are rather heterogeneous and include only a few companies of each origin. Danish, US, Italian, and Portuguese companies showed stable values next to the full sample mean levels for reinsurance and leverage. However, German companies presented much higher values: reinsurance ratios oscillated from 60 to $95 \%$ after the outbreak of the First World War and during the monetary distortions of the 1920s, while leverage in this period in the case of Nord Deutsche was no lower than 600. Finally, Swiss companies displayed an interesting asymmetry: while leverage levels remain between 200 and 300 for all companies - that is, lower than the rest of the sample - reinsurance ratios varied from the approximately $55 \%$ of La Baloise to the $8 \%$ of La Federale. This could be explained as a Swiss anomaly, since these companies had direct access to a highly efficient capital market and, at the same time, can be expected to have been in close contact with one of the most advanced reinsurance markets in the world. In this scenario, the decision to reinsure would not arise from a financial necessity, but from a managerial decision related to other elements. For example, the low rates of retention of La Baloise could be explained with the tight links the company had with the reinsurance industry: certainly, the office was very close to the Basler Handelbank, which was one of the main shareholders and founding member of Swiss $R e .^{73}$ As a consequence of this high heterogeneity, we include these companies in the full sample, but not as a separate analysis group.

\footnotetext{
${ }^{73}$ James et al., The value of risk, 247.
} 
Regarding the Spanish, British, and French companies, the figures indicate a positive correlation between reinsurance and leverage, despite a high dispersion of values. With regard to loss ratio indicators, one can see that British and French fire insurance companies had high figures compared to the Spanish ones (and the other nationalities). Figures on volatility show that British insurers especially faced great variations in loss ratio. A close examination shows that most jumps in the loss ratio are attributed to two kinds of extreme values: those produced by abnormally low figures for premiums earned due to entering or exiting the market, as in the case of Legal and General and General Accident and Fire; but also six entrances corresponding to catastrophic losses during 1909, 1912 and 1914. Liquidity indicators show the managerial practices of foreign insurers that would keep minimum resources in the country in order to maximize the returns of their investment in the host market, while Spanish companies displayed a somewhat greater preference for maintaining liquid assets. However, both groups are highly heterogeneous, as indicated by standard deviation values. With regard to size, it shows homogeneous values for all nationalities, while in the case of age there are large internal deviations inside groups and differences between nationalities in favour of foreign companies, which could balance the levels of market knowledge for different countries of origin. Finally, as a cross variable, data on mutual societies have been separated from the Spanish sample. As shown in the table, these societies are the most prone to use reinsurance, but are also those with higher levels of leverage and lower levels of liquidity. In parallel, their loss ratios are below the mean of the market and they are among the youngest companies operating in the fire branch. 
To empirically examine the determinants of reinsurance, we have employed a panel data approach. Since one of the key variables (nationality) is time-invariant, we start with a basic random-effects model, using the following regression equation:

$$
\operatorname{REIN}_{i t}=\alpha+\sum \beta X_{i t}+\beta Y_{t}+\beta U_{t}+\beta V_{t}+\varepsilon_{i t}
$$

where $R E I N_{i t}$ is the ratio of reinsured premiums of company $i$ in year $t ; X_{i t}$ represents the nationality of the company (NATSP for Spanish; NATUK for British; NATFR for French); $Y_{t}$ refers to organizational form $(\mathrm{OF}) ; U_{t}$ is the vector of macro variables including exchange rate (EXCH) and GDP growth in real terms (GRTH); and $V_{t}$ is the vector of firm-specific variables including LEV, LOSS, LIQ, SIZE and AGE.

To identify the pairwise relation across the variables employed in our analysis, we build a correlation coefficient matrix including nationality, organizational form, country-level data, and firm-specific indicators so as to identify the sign, intensity, and statistical significance of the pairwise relations between variables. As shown in Table 3, nationality and organizational form have a significant correlation with reinsurance: Spanish companies are expected to reinsure more than British ones, while mutual societies are more prone to purchase reinsurance than are stock companies. With regard to macroeconomic variables, GDP growth has an insignificant impact on reinsurance, while exchange rate shows a significant negative correlation, as hypothesized.

Firm-specific variables perform in diverse ways. Leverage is significantly and positively correlated with reinsurance, as predicted. Loss ratio shows a weak but statistically significant inverse correlation with reinsurance, which is contradictory to the risk aversion framework. As we expected, age is significantly and inversely correlated with reinsurance, while size and, especially liquidity, have less impact. Regarding correlations between independent variables, nationality indicators show the 
highest (and most negative) levels, since they are mutually incompatible. In parallel, organizational form shows a significant correlation with Spanish nationality, given that all mutual societies included in the sample are Spanish. In the group of macroeconomic variables, there is a significant and negative correlation between growth and exchange rate.

Firm-specific variables are highly correlated: concretely, leverage is significantly correlated to liquidity, age, and size, which in turn shows a significant correlation with liquidity and age. Although the coefficient values are below 0.5 , low significance and the multiple relations between firm-specific variables limit their use due to multicollinearity. Certainly, despite the , initially observed , high correlation of leverage with reinsurance and the statements in the previous literature, the interconnections between variables pose restrictions that severely limit its explanatory power and fit in the model. In addition, leverage shows a problem of causality: the results do not allow a determination of whether high levels of leverage make companies reinsure more or whether companies using more reinsurance underwrite more risks and, in turn, raise their leverage. In contrast, size seems to capture a large fraction of the variation in all other independent variables; consequently, it can take on a "catchall" variable for firm characteristics. 
. Table 3. Reinsurance determinants in fire insurance market (1908-1934). Correlation coefficients matrix.

\begin{tabular}{lccccccccccc} 
& REIN & NATSP & NATUK NATFR & ORG & EXCH & GRTH & LEV & LOSS & LIQ & SIZE \\
\cline { 2 - 10 } NATSP & $.338^{\mathrm{a}}$ & 1 & - & - & - & - & - & - & - & - & - \\
NATUK &.$- .405^{\mathrm{a}}$ & $-.455^{\mathrm{a}}$ & 1 & - & - & - & - & - & - & - & - \\
NATFR & -.066 & $-.404^{\mathrm{a}}$ & $-.386^{\mathrm{a}}$ & 1 & - & - & - & - & - & - & - \\
ORG & $.294^{\mathrm{a}}$ & $.170^{\mathrm{a}}$ & $-.077^{\mathrm{b}}$ & $-.068^{\mathrm{b}}$ & 1 & - & - & - & - & - & - \\
EXCH & $-.107^{\mathrm{a}}$ & -.028 & .059 & -.020 & $-.098^{\mathrm{a}}$ & 1 & - & - & - & - & - \\
GRTH & .015 & .005 & .018 & -.003 & -.009 & $-.202^{\mathrm{a}}$ & 1 & - & - & - & - \\
LEV & $.329^{\mathrm{a}}$ & $.183^{\mathrm{a}}$ & $-.131^{\mathrm{a}}$ & $-.090^{\mathrm{b}}$ & $.176^{\mathrm{b}}$ & $-.171^{\mathrm{b}}$ & -.035 & 1 & - & - & - \\
LOSS & $-.229^{\mathrm{a}}$ & $-.123^{\mathrm{b}}$ & $.212^{\mathrm{b}}$ & -.015 & .040 & .038 & -.009 & $-.090^{\mathrm{b}}$ & 1 & - & - \\
LIQ & $.141^{\mathrm{a}}$ & $.275^{\mathrm{a}}$ & $-.189^{\mathrm{a}}$ & $-.130^{\mathrm{a}}$ & -.021 & $.107^{\mathrm{a}}$ & $-.078^{\mathrm{b}}$ & $.160^{\mathrm{a}}$ & -.056 & 1 & - \\
SIZE & $.094^{\mathrm{b}}$ & $.194^{\mathrm{a}}$ & -.058 & .046 & -.011 & $-.128^{\mathrm{b}}$ & -.009 & $.369^{\mathrm{a}}$ & .044 & $-.266^{\mathrm{b}}$ & 1 \\
AGE & $-.161^{\mathrm{a}}$ & $-.176^{\mathrm{a}}$ & $.219^{\mathrm{a}}$ & $.109^{\mathrm{a}}$ & $-.135^{\mathrm{a}}$ & $-.144^{\mathrm{a}}$ & .019 & $.113^{\mathrm{a}}$ & $.076^{\mathrm{b}}$ & -.074 & $.470^{\mathrm{a}}$ \\
\hline
\end{tabular}

a, b Statistically significant at the $1 \%$ and $5 \%$ levels

Note: REIN $=$ Premiums reinsured $/$ Premiums earned, in $\%$; NTSP $=1$ for Spanish, 0 for other; NTUK $=1$ for British, 0 for other; NTFR $=1$ for French, 0 for other; ORG = 1for mutual, 0 for stock company; EXCH = Official exchange rate of Peseta $/ 100$ French Francs $(\mathrm{FF})$; GRTH = \% rate of GDP growth in real terms; LEV = Premiums earned / Ongoing-risks reserves, in \%; LOSS = Claims / Premiums earned, in \%; LIQ = Cash + Bank accounts / Ongoing-risks reserves, in \%; SIZE $=$ Natural logarithm of premiums earned; AGE $=\mathrm{n}^{\circ}$ of years since the first official registration in fire branch in Spain.

Source: AGA (1) 26 - Cajas I-1 to I-141 Top. 13/31 and AGA (1) 26 - Cajas 11/02131 to 11/02180; Comisaría General de Seguros, Memoria sobre las entidades de seguros que operan en España, Years 1911, 1912, 1913, 1915. 
We thus use two different explanatory models, using nationality and organizational forms separately. Both are combined with exchange rate and the main set of firm-specific indicators, namely: leverage, loss ratio, liquidity, and size. We use these firm-specific indicators in order to control for individual differences not captured by non-firm-specific variables. Two variables from the initial dataset have been dropped: age, due to its high positive correlation with size, which is consistent with the literature; and growth, since it shows no impact on any variable. In order to utilize the most appropriate model, we have run specification tests. A Hausman test showed that the unobserved heterogeneity was important, and that a fixed-effects model that accounts for unobserved firm-specific influences was appropriate. One disadvantage of a fixedeffects estimator is that the influence of time-invariant variables may to some extent be included in the firm-specific fixed effects and not actually attributed to the respective variable. Unfortunately, this could be the case for most of the independent variables in our analysis.

To control for the robustness of the outcome with regard to the specification applied, we have run both random effects and fixed effects, along with between estimators. Comparing the results across specifications, only minor differences arise. The comparison between fixed-effects and random-effects models shows that the influence of exchange rate and size remains at the same level when unobserved interactions are removed, given that coefficients for both models display differences below 10\% (see Appendix 1). With respect to between estimators, nationality holds its influence for both the Spanish and British cases. As expected, exchange rate has no significant influence since it is a country-level indicator that affects all companies equally, so it cannot explain variations between firms. According to Wooldridge, this 
would allow for the assumption of a minimum impact of unobserved influences, so we can use the random-effects estimators to measure the impact of nationality. ${ }^{74}$

Table 4 shows the determinants of reinsurance demand, estimated using a random-effects model including the different nationalities as a variable. The randomeffects models confirm the role of nationality as a statistically significant determinant of reinsurance practices. While the French and Other nationalities have no significance in the model, both Spanish (NATSP) and British (NATUK) show p-values below 0.005 . As we expected, NATSP is positively related with the dependent variable, meaning that Spanish companies are more prone to reinsure. According to the figures, the influence of nationality is continuous and increases over the period. The estimated coefficient for the full period shows that domestic Spanish companies reinsured on average 22\% more than other nationalities. To make a rough comparison of the estimate on the timeinvariant variable, the random-effects estimate of nationality is compared with the fixed-effects term aggregated by nationality. It is shown that the estimated fixed term by nationality also shows a $22 \%$ higher reinsurance share for companies with Spanish nationality compared to non-Spanish companies (see Appendix 2).

Within our ruin theory framework, this inclination connects directly with the main features of the financial system and the fire insurance market in Spain: in a period of market growth, companies operating in Spain would have few options. ${ }^{75}$ Firstly, the shortcomings of the low diversified financial system posed obstacles to the access to new capital resources for Spanish insurance companies, while French and British companies benefited from their links with their mother offices and, in turn, with highly

\footnotetext{
${ }^{74}$ Wooldridge, Econometric analysis.

${ }^{75}$ Deelstra and Plantin, Risk theory and reinsurance.
} 
Table 4. Reinsurance determinants in fire insurance market (1908-1934). Random effect linear regression models with nationality, exchange rate and firm-specific variables.

\begin{tabular}{|c|c|c|c|c|c|c|c|c|c|c|}
\hline & \multicolumn{5}{|c|}{ Spanish } & \multicolumn{5}{|c|}{ British } \\
\hline & $1908-34$ & 1908-19 & $1915-9$ & $1920-9$ & $1920-34$ & $1908-34$ & 1908-19 & $1915-9$ & $1920-9$ & $1920-34$ \\
\hline & (1) & (2) & (3) & (4) & (5) & (6) & $(7)$ & (8) & (9) & $(10)$ \\
\hline \multirow{2}{*}{ NAT* } & $21.459^{\mathrm{a}}$ & $14.482^{b}$ & $21.206^{\mathrm{a}}$ & $26.655^{a}$ & $29.184^{\mathrm{a}}$ & $-22.480^{\mathrm{a}}$ & $-20.414^{\mathrm{a}}$ & $-25.455^{\mathrm{a}}$ & $-25.747^{\mathrm{a}}$ & $-27.159^{a}$ \\
\hline & $(5.429)$ & (6.908) & (7.897) & (6.013) & $(5.707)$ & $(6.098)$ & $(6.295)$ & $(6.567)$ & $(6.633)$ & (6.678) \\
\hline \multirow{2}{*}{$\mathrm{EXCH}$} & $-7.242^{\mathrm{a}}$ & $-23.897^{\mathrm{a}}$ & $-41.319^{a}$ & $-11.279^{a}$ & $-5.562^{c}$ & $-7.116^{\mathrm{a}}$ & $-23.829^{a}$ & $-39.644^{\mathrm{a}}$ & $-10.913^{\mathrm{a}}$ & -5.262 \\
\hline & $(1.718)$ & $(5.545)$ & $(11.591)$ & $(3.386)$ & $(3.659)$ & (1.719) & $(5.522)$ & (11.509) & $(3.394)$ & $(3.666)$ \\
\hline \multirow{2}{*}{ LEV } & 0.001 & -0.009 & $0.021^{\mathrm{c}}$ & 0.001 & 0.002 & 0.001 & -0.008 & $0.025^{b}$ & 0.001 & 0.002 \\
\hline & $(0.005)$ & $(0.009)$ & $(0.013)$ & $(0.006)$ & $(0.006)$ & $(0.005)$ & $(0.009)$ & $(0.012)$ & $(0.006)$ & $(0.007)$ \\
\hline \multirow{2}{*}{ LOSS } & -0.023 & -0.019 & 0.053 & 0.009 & -0.021 & -0.022 & -0.015 & 0.055 & 0.009 & -0.022 \\
\hline & $(0.019)$ & $(0.031)$ & $(0.043)$ & $(0.020)$ & $(0.020)$ & $(0.019)$ & $(0.031)$ & $(0.043)$ & $(0.020)$ & $(0.019)$ \\
\hline \multirow{2}{*}{ LIQ } & 0.010 & 0.009 & $0.028^{b}$ & -0.008 & -0.012 & $0.011^{b}$ & 0.010 & $0.031^{b}$ & 0.009 & -0.012 \\
\hline & $(0.006)$ & $(0.009)$ & $(0.014)$ & $(0.008)$ & $(0.009)$ & $(0.006)$ & $(0.010)$ & $(0.014)$ & $(0.008)$ & $(0.009)$ \\
\hline \multirow{2}{*}{ SIZE } & $-4.287^{\mathrm{a}}$ & $-6.907^{\mathrm{a}}$ & $-6.853^{\mathrm{a}}$ & $-4.862^{\mathrm{a}}$ & $-1.646^{c}$ & $-4.185^{\mathrm{a}}$ & $-6.536^{\mathrm{a}}$ & $-5.703^{a}$ & $-4.673^{\mathrm{a}}$ & -1.470 \\
\hline & $(0.947)$ & $(1.850)$ & $(2.221)$ & $(1.135)$ & $(1.076)$ & $(0.948)$ & $(1.761)$ & $(1.994)$ & $(1.142)$ & $(1.093)$ \\
\hline \multirow{2}{*}{ Const. } & $79.083^{a}$ & $131.906^{\mathrm{a}}$ & $127.615^{\mathrm{a}}$ & $84.388^{\mathrm{a}}$ & $42.743^{\mathrm{a}}$ & $92.823^{\mathrm{a}}$ & $138.725^{\mathrm{a}}$ & $126.693^{\mathrm{a}}$ & $100.833^{\mathrm{a}}$ & $60.131^{a}$ \\
\hline & (11.882) & $(23.267)$ & $(30.922)$ & $(14.015)$ & $(13.145)$ & $(12.035)$ & $(23.161)$ & $(29.171)$ & $(14.240)$ & $(13.425)$ \\
\hline \multicolumn{11}{|l|}{$\mathrm{R}^{2}$} \\
\hline within & 0.067 & 0.172 & 0.219 & 0.127 & 0.028 & 0.066 & 0.168 & 0.202 & 0.127 & 0.028 \\
\hline between & 0.151 & 0.009 & 0.193 & 0.215 & 0.349 & 0.141 & 0.094 & 0.361 & 0.166 & 0.250 \\
\hline overall & 0.109 & 0.008 & 0.193 & 0.158 & 0.220 & 0.122 & 0.053 & 0.305 & 0.119 & 0.198 \\
\hline
\end{tabular}

* NATSP for Spanish and NATUK for British companies.

${ }^{\mathrm{a}, \mathrm{b}, \mathrm{c}}$ Statistically significant at the $1 \%, 5 \%$ and $10 \%$ level.

Note: $\mathrm{EXCH}=$ Official exchange rate of Peseta $/ 100$ French Francs (FF); LEV = Premiums earned $/$ Ongoing-risks reserves, in \%; LOSS = Claims / Premiums earned, in \%; LIQ = Cash + Bank accounts / Ongoing-risks reserves, in \%; SIZE = Natural logarithm of premiums earned.

Source: AGA (1) 26 - Cajas I-1 to I-141 Top. 13/31 and AGA (1) 26 - Cajas 11/02131 to 11/02180; Comisaría General de Seguros, Memoria sobre las entidades de seguros que operan en España, Years 1911, 1912, 1913, 1915. 
developed capital markets. ${ }^{76}$ Secondly, the structure of the Spanish fire insurance market, with a cartel of stock companies competing against mutual societies, and a wide group of domestic insurers lobbying against foreign offices, would not have allowed the raising of prices. ${ }^{77}$ Consequently, Spanish companies would have used reinsurance as the only possible response to the sustained growth of the insurance market, due to the chronic lack of capitalization and the rigidities of the financial system. In other words, it could be said that reinsurance became a key device for the growth and development of the Spanish fire insurance market. In contrast to this performance, the negative sign in the coefficient for NATUK would indicate the reluctance of British companies to purchase reinsurance. Certainly, the contact British branches had with their headquarters would provide them with direct access to the efficient British capital market. Consequently, the only remaining motive for British companies to reinsure would be in order to reduce underwriting risks. ${ }^{78}$

In parallel, exchange rate impacts on reinsurance operations in such a way that the increase/decrease of the rate, which results in the decrease/increase of the purchasing power of the Peseta, makes companies purchase less/more reinsurance abroad. This impact was especially strong during the First World War, when the value of the main European currencies dropped drastically. In fact, despite the high inflation rates suffered in Spain, the monetary effects of the war resulted in a $32 \%$ fall of the French Franc exchange rate from 1914 to 1919, while the British Pound dropped 27\% (See Appendix 3). However, the monetary disorders during the 1920s show much less influence on Spanish reinsurance practices, as the links with the German market were

\footnotetext{
${ }^{76}$ Malo de Molina and Martín-Aceña, The Spanish Financial System.

77 Pons, 'Multinational enterprises', 108, and Tortella et al., Historia del seguro. The third option proposed by Deelstra and Plantin would be the increase of low-variance risks contracts, which would not be a real option since these kinds of risks are a minority on the market.

78 A third motivation analysed by previous literature, the use of reinsurance as a method of internationalization, would not be relevant in this context, since most British companies had been established in Spain for decades in the period of study.
} 
very weak. With regard to size, it comprises a statistically significant impact on reinsurance ( $\mathrm{p}$-value $<0.001$ ): as stated in the previous literature, small companies purchased more reinsurance so as to increase their presence on the market without accumulating new capital resources. Furthermore, they are more sensitive to loss volatility since their ratio of liabilities over assets is higher. ${ }^{79}$ In addition, the characteristic of this variable as a "catchall" for the variations in the rest of the firmspecific variables contributes to its high significance (see Appendix 4). Finally, the other firm-specific variables show no significance in our model, as they are affected by the aforementioned multicollinearity problems.

In relation to the role of organizational form, the Hausman test was not statistically significant ( $\mathrm{p}$-value $>0.010$ ), indicating that a random-effects model was more appropriate. Table 5 displays the second set of estimators applied over a sample restricted to Spanish companies. The performance of organizational form shows a strong and positive impact in the use of reinsurance ( $\mathrm{p}$-values $<0.005)$. This is consistent with the previous literature: mutual societies purchased more reinsurance than did stock companies, since they suffered from extra capital constraints due to their lack of equity capital. ${ }^{80}$ In the case of Spanish mutual societies, this tendency to reinsure has been noted as a growth strategy in individual cases like Mutua General de Seguros. ${ }^{81}$ According to the results, this was likely a common practice in property insurance, in such a way that mutual societies collected high commissions and kept their position in the local markets, where they operated through an intense use of reinsurance.

\footnotetext{
${ }^{79}$ Mayers and Smith, 'Evidence from reinsurance market', Adams, 'The reinsurance decision', Adiel, 'Reinsurance' and Dickson and Waters, 'Reinsurance and ruin'.

${ }^{80}$ Pearson, 'Development of reinsurance', noted the use of reinsurance as a way for small stock companies and mutual societies to increase their market share, while Adams et al., 'Mutuality', Adams et al., 'Competing models', Kader et al, 'Determinants of reinsurance' and Lilljegren and Andersson, 'Variation in organizational form' found that Swedish mutual societies were less prone to reinsure since they were relatively less exposed to unexpectedly high losses.

${ }^{81}$ Gutiérrez and Pons, 'Risk management'.
} 
Table 5. Reinsurance determinants in Spanish fire insurance companies (1908-1934). Random effect linear regression with organizational form, exchange rate and firmspecific variables.

\begin{tabular}{ccc}
\hline & $(1)$ & $(2)$ \\
\cline { 2 - 3 } ORG & $41.378^{\mathrm{a}}$ & $35.302^{\mathrm{a}}$ \\
& $(12.205)$ & $(13.108)$ \\
\hline \multirow{2}{*}{ FALSE } & $14.100^{\mathrm{c}}$ & $12.702^{\mathrm{c}}$ \\
& $(7.262)$ & $(7.404)$ \\
\hline \multirow{2}{*}{ EXCH } & $-15.578^{\mathrm{a}}$ & $-15.880^{\mathrm{a}}$ \\
& $(2.840)$ & $(2.996)$ \\
\hline \multirow{2}{*}{ LEV } & & $0.016^{\mathrm{b}}$ \\
& & $(0.008)$ \\
\hline \multirow{2}{*}{ LOSS } & & 0.068 \\
& & $(0.046)$ \\
\hline \multirow{2}{*}{ LIQ } & & -0.009 \\
& & $(0.008)$ \\
\hline \multirow{2}{*}{ SIZE } & $-3.407^{\mathrm{b}}$ & $-4.985^{\mathrm{a}}$ \\
& $(1.501)$ & $(1.702)$ \\
\hline \multirow{2}{*}{ Const. } & $88.492^{\mathrm{a}}$ & $100.606^{\mathrm{a}}$ \\
\hline R & $(20.003)$ & $(22.382)$ \\
within & & \\
between & 0.136 & 0.172 \\
overall & 0.394 & 0.425 \\
a, b, & 0.195 & 0.232
\end{tabular}

$\overline{\mathrm{a}, \mathrm{b}, \mathrm{c}}$ Statistically significant at the $1 \%, 5 \%$ and $10 \%$ level.

Note: $\mathrm{ORG}=1$ for mutual, 0 for stock company; FALSE $=1$ if false Spanish company, 0 othervise; EXCH = Official exchange rate of Peseta / 100 French Francs (FF); GRTH = \% rate of GDP growth in real terms; LEV = Premiums earned / Ongoing-risks reserves, in \%; LOSS $=$ Claims $/$ Premiums earned, in \%; LIQ = Cash + Bank accounts / Ongoing-risks reserves, in $\%$; SIZE = Natural logarithm of premiums earned.

Source: AGA (1) 26 - Cajas I-1 to I-141 Top. 13/31 and AGA (1) 26 - Cajas 11/02131 to 11/02180; Comisaría General de Seguros, Memoria sobre las entidades de seguros que operan en España, Years 1911, 1912, 1913, 1915.

To control for the potential effect of foreign governed Spanish companies, we included a dummy for 'false Spanish companies'. The impact of foreign governance on reinsurance was statistically significant and positive in both models. However, the performance of the three false Spanish companies included in our sample requires further explanation. Numancia was included in a group of German-owned capital with others offices such as Plus Ultra, which operated in the transport branch. In the second case, Hispania was founded in 1902 by investors from Catalonia in order to sell workaccident insurance policies. In 1911, it began operations in the fire line but, three years 
later, it was bought by the Swiss Zurich. Attempting to specialise the company in the work-accident line, the new managers assumed the policies in force, and in 1916 left the fire branch. As a result, most of the business in 1914, 1915 and 1916 was reinsured to Zurich. ${ }^{82}$ Finally, La Unión y el Fénix Español was constituted with a $58.22 \%$ of nonSpanish capital, though it was declining over the following decades. ${ }^{83}$ In parallel though, the company maintained a special agency in Paris whose direct business was devoted to the Spanish market. Additionally, the financial sources of the company were based in Spain, showing close relations with the Banco de España and, during the 1920s, with the Banco Hipotecario de España. In this way, the special reinsurance performance could be related not to its foreign shareholders, but to its role as the gateway to foreign reinsurance for a substantial share of Spanish insurers. ${ }^{84}$ Supporting the results obtained in the model presented in Table 4, exchange rate holds a significant and negative correlation with reinsurance purchases. As regards firm-specific variables, size is again the only one with a statistically significant impact on reinsurance (at the $5 \%$ level in the complete model). In contrast, leverage, loss ratio, and liquidity show no significance within the model.

Taking into account the results shown in both models, reinsurance seems to be a widely used device by Spanish companies in order to enhance their underwriting capacity. In fact, controlling for firm-specific variables and paying attention to variable coefficients (Table 4), this indicates that Spanish nationality holds a strong preference for reinsurance. In view of the differences derived from nationality regarding access to capital resources, this strong systematic preference could be considered to be due to the

\footnotetext{
${ }^{82}$ Pons, El grupo Zurich.

${ }^{83}$ Tortella et al., La Historia del seguro, 121.

${ }^{84}$ Gutiérrez and Pons, 'Risk management', 6-9, describes this role and connects it to the international scope of the company.
} 
contribution of foreign reinsurance as a funding provider to enhance the underwriting capacity on the undercapitalized Spanish insurance market.

Furthermore, the financial role of reinsurance as a key element in the development of the Spanish insurance market connects with other dimensions noted in the previous literature and related to market structuring and internationalization management. It seems clear that, as stated in the previous literature, reinsurance served as the main channel for small local companies and mutual societies to participate in a dense network managed by big companies, such as La Unión y el Fénix Español, capable of covering local risks by using their interregional and even international underwriting capacity. ${ }^{85}$ Certainly, reinsurance played a major role in the globalization of Spanish risks, but also in the strategy of internationalizing Spanish offices such as $L a$ Unión y el Fénix Español. Following the procedure of British companies like Phoenix Assurance, analysed by Trebilcock and Kobrak, this company used reinsurance so as to break into new markets such as France, Italy, Belgium and the United States. ${ }^{86}$

\section{IV}

Knowledge and technology transfer benefitted insurance providers in continental Europe. The development of new devices like reinsurance allowed them to deal with larger risks and with financial constraints. Certainly, as an imperfect substitute for capital, reinsurance enhanced underwriting capacity and acted as a funding provider for insurers. Simultaneously, reinsurers built wide networks of risk exchange which, in turn, contributed to modernizing peripheral latecomers.

\footnotetext{
${ }^{85}$ Gutiérrez and Pons, 'Risk management'

${ }^{86}$ Idem. For the case of Phoenix, see Trebilcock, Phoenix Assurance, Kobrak, 'USA: International attraction'.
} 
In the Spanish case, the insurance industry developed quickly together with the rest of the economy from 1870 to the outbreak of the Civil War in 1936. Foreign investment and new management focuses contributed to the growth of the industry. However, the scarcity of capital resources and the undercapitalization issue remained the main shortcomings on the Spanish insurance market throughout the period. Systemic imbalances and rigidities, as well as a lack of diversification in the financial system, defined an insurance industry affected by capital constraints and high levels of leverage.

According to the empirical results, reinsurance played a key role in avoiding these shortcomings as an enhancer of the underwriting capacity of domestic insurers and, in parallel, as a device for dealing with undercapitalization issues. As expected, nationality and organizational form operated as high-impact factors defining reinsurance strategies. Certainly, when controlling for firm-specific variables, we note that the performance of Spanish insurers relied heavily on their access to the reinsurance market, as they were significantly more prone to reinsure than were British and French offices. In contrast to foreign companies, and taking into account the differences related to nationality regarding the access to capital markets, reinsurance served as a major source of capital funding for domestic insurers. These findings are consistent with previous studies dealing with the organization of reinsurance flows in Spain and the links between local markets and global networks. In this sense, our study contributes by empirically testing the impact of reinsurance on undercapitalized and developing economies, and by offering a quantitative measure of this influence on the modernization and development of the insurance market.

Our analysis further suggests that around $20 \%$ of the underwriting capacity on the undercapitalized Spanish insurance market was supplied by foreign reinsurance 
networks. We show that the provision of foreign capital was a necessity to keep pace with the demand arising from the process of capital formation; fire insurance meet a critical need in both improving financial protection (collateral) and mitigating indemnity of losses due to unexpected risks. However, the capital import may have exacerbated the balance of payment difficulties unless the productivity growth following the reinforced capital formation was strong enough to balance by greater commodity export.

\section{REFERENCES}

Adams, M.B., 'The reinsurance decision in life insurance firms: an empirical test of the risk-bearing hypothesis', Accounting and Finance, 36 (1996), pp. 15-30.

Adams, M.B., Andersson, L.F., Jia, J.Y. and Lindmark, M., 'Mutuality as a control for information asymmetry: a historical analysis of the claims experience of mutual and stock fire insurance companies in Sweden 1889-1939', Business History, 53 (2011), pp. 1074-91.

Adams, M.B., Andersson, L.F., Lindmark, M. and Veprauskaite, E., 'Competing models of organizational form: risk management strategies and underwriting performance in the Swedish fire insurance market between 1903 and 1939', Journal of Economic History, 72 (2012), pp. 990-1014.

Adiel, R., 'Reinsurance and the management of regulatory ratios and taxes in the property-casualty insurance industry', Journal of Accounting and Economics, 22 (1996), pp. 207-40.

Alborn, T., Regulated lives: life insurance and British society, 1800-1914 (Toronto, 2009). 
Bartolomé Rodríguez, I., Martín-Aceña, P. and Martínez Ruiz, E., 'A Spanish tale: the Great Depression versus the Great Recession'. Communication presented at the XI Spanish Economic History Association Congress, Madrid, 4 September 2014. (Consulted on 10/10/2014).

\section{http://www.aehe.net/xicongreso/pdfs/sp_bartolome_martinez.pdf}

Berger, L.A., Cummins, J.D. and Tennyson, S., 'Reinsurance and the liability insurance crisis', Journal of Risk and Uncertainty, 5 (1992), pp. 253-72.

Borscheid, P. and Haueter, N.V., eds., World insurance. The evolution of a global risk network (Oxford, 2012).

Canals i Vilaró, S., Cuestiones económicas: el Comité Oficial de Seguros y el reaseguro obligatorio del Estado (Barcelona, 1923).

Carreras, A. and Tafunell, X., dirs., Estadísticas históricas de España (v. III) (Madrid, 2005).

Cenamor Val, H., El seguro sobre la vida en España en 1934 (Madrid, 1935).

Cole, R.C. and McCullough, K.A., 'A reexamination of the corporate demand for reinsurance', The Journal of Risk and Insurance, 73 (2006), pp. 169-92.

Comín Comín, F., 'Las crisis de la deuda: el largo camino desde los impagos a la gestión responsable', in P. Martín-Aceña, E. Martínez Ruiz and M.A. Pons Brías, coords., Las crisis financieras en la España contemporánea, 1850-2012 (Barcelona, 2013), pp. 197-240.

Cuevas Casaña, J., 'Las crisis bursátiles, 1850-2000. De la burbuja ferroviaria a la tecnológica', in P. Martín-Aceña, E. Martínez Ruiz and M.A. Pons Brías, Las crisis financieras en la España contemporánea, 1850-2012 (Barcelona, 2013), pp. 159-96.

Deelstra, G. and Plantin, E., Risk theory and reinsurance (London, 2014). 
Dickson, D.C.M. and Waters, H.R., 'Reinsurance and ruin', Insurance: Mathematics and Economics, 19 (1996), pp. 61-80.

Doherty, N.A. and Tinic, S.N., 'Reinsurance under conditions of capital market equilibrium: a note', The Journal of Finance, 36 (1981), pp. 949-53.

European Commission, International Monetary Fund, Organisation for Economic Cooperation and Development, United Nations and World Bank, System of National Accounts 2008 (New York, 2009).

Frax Rosales, E. and Matilla Quiza, M.J., 'Los seguros en España: 1830-1934', Revista de Historia Económica, 14 (1996), pp. 183-203.

Gadea, M. D. and Sabaté, M., 'The European periphery in the Era of the Gold Standard: the case of the Spanish Peseta and the Pound Sterling from 1883 to 1931', Open Economies Review, 15 (2004), pp. 63-85.

Garven, J.R. and Lamn-Tennant, J., 'The demand for reinsurance: theory and empirical tests', Assurances, 71 (2003), pp. 217-38.

Gerathewohl, K., Reinsurance: principles and practice (London, 1985).

Gerschenkron, A., Economic backwardness in historical perspective (Cambridge, 1962).

Golding, C.E., A history of reinsurance (London, 1927).

Gutiérrez González, P., El control de divisas durante el primer franquismo. La intervención del reaseguro (1940-1952) (Madrid, 2014).

Gutiérrez González, P. and Pons Pons, J., 'Risk management and reinsurance strategies in the Spanish insurance market (1880-1940)', Business History, (2016).

http://dx.doi.org/10.1080/00076791.2016.1187136

James, H., Borscheid, P., Gugerli, D. and Straumann, T., The value of risk. Swiss Re and the history of reinsurance (Oxford, 2013). 
Jovanovic, B., 'Selection and evolution of industry', Econometrica, 50 (1982), pp. 64970.

Kader, H.A., Adams, M. Andersson, L.F. and Lindmark, M., 'The determinants of reinsurance in the Swedish property fire insurance market during the interwar years, 1919-39’, Business History, 52 (2010), pp. 268-84.

Kobrak, C., 'USA: The international attraction of the US insurance market', in P. Borscheid and N.V. Haueter, (eds.), World Insurance. The Evolution of a Global Risk Network (Oxford, 2012), pp. 274-310.

Krugman, P., 'A model of innovation, technology transfer and the world distribution of income', Journal of Political Economy, 87 (1979), pp. 253-66.

Lamn-Tennant, J. and Starks, L., 'Stock versus mutual ownership structures: the risk implications', Journal of Business, 66 (1993), pp. 29-46.

Lilljegren, J. and Andersson, L.F., 'Variation in organizational form across lines of property insurance: Sweden, 1913-1939', Financial History Review, 21 (2014), pp. $77-101$.

Malo de Molina, J.L. and Martín-Aceña, P., eds., The Spanish financial system. Growth and development since 1900 (Basingstoke, 2011).

Martín-Aceña, P., 'Desarrollo y modernización del sistema financiero, 1844-1935', in N. Sánchez Albornoz, ed., La modernización económica de España (Madrid, 1987), pp. 121-46.

Martín-Aceña, P., 'Spain during the classical Gold Standard years, 1880-1914', in M. Bordo and F. Capie, eds., Monetary regimes in transition (Cambridge, 1993), pp. $135-72$. 
Martín-Aceña, P., 'The Spanish banking system from 1900 to 1975', in J. L. Malo de Molina and P. Martín-Aceña, eds., The Spanish financial system. Growth and development since 1900 (Basingstoke, 2011), pp. 99-144.

Martín-Aceña, P., 'Crisis bancarias. Nada nuevo bajo el sol', in P. Martín-Aceña, E. Martínez Ruiz and M.A. Pons Brías, coords., Las crisis financieras en la España contemporánea, 1850-2012 (Barcelona, 2013), pp. 53-114.

Martínez Ruiz, E., 'Papel mojado. Crisis inflacionarias', in F. Comín Comín and M. Hernández Benítez coords., Crisis económicas en España. 1300-2012: lecciones de la historia (Madrid, 2013), pp. 203-26.

Mayers, D. and Smith, C.W., 'On the corporate demand for insurance', Journal of Business, 55 (1982), pp. 281-96.

Mayers, D. and Smith, C.W., 'On the corporate demand for insurance: evidence from the reinsurance market', Journal of Business, 63 (1990), pp. 19-40.

Pearson, R., 'The development of reinsurance markets in Europe during the nineteenth century', Journal of European Economic History, 24 (1995), pp. 557-72.

Pearson, R., 'The birth pains of a global reinsurer. Swiss Re of Zürich, 1864-79', Financial History Review, 8 (2001), pp. 27-47.

Pearson, R., Insuring the Industrial Revolution: fire insurance in Great Britain, 17001850 (London, 2004).

Pearson, R., 'The growth, organization, and diffusion of the British insurance industry', in Instituto de Ciencias del Seguro, ed., Encuentro internacional sobre la historia del seguro (Madrid, 2010), pp. 13-42.

Pearson, R., 'Las compañías de seguros en España antes de 1914', in J. Pons Pons and M. A. Pons Brías, eds., Investigaciones históricas sobre el seguro español (Madrid, 2010), pp. 101-30. 
Pearson, R., 'United Kingdom: Pioneering insurance internationally', in P. Borscheid and N.V. Haueter, eds., World Insurance. The Evolution of a Global Risk Network, (Oxford, 2012), pp. 67-97.

Plantin, G., 'Does reinsurance need reinsurers?', Journal of Risk and Insurance, 73 (2006), pp. 153-68.

Plantin, G. and Rochet, J.C., When insurers go bust: an economic analysis of the role and design of prudential regulation (Princeton, 2007).

Pons Brías, M.A., 'The main reforms of the Spanish financial system', in J. L. Malo de Molina and P. Martín-Aceña, eds., The Spanish financial system. Growth and development since 1900 (Basingstoke, 2011), pp. 71-98.

Pons Pons, J., 'Las estrategias de crecimiento de las compañías de seguros en España 1900-1940' (2002) (Consulted on 21/10/2015).

ftp://ftp.fundacionsepi.es/phe/hdt2002_1.pdf

Pons Pons, J., 'Diversificación y cartelización en el seguro español, 1914-1935', Revista de Historia Económica, 21 (2003), pp. 567-92.

Pons Pons, J., 'Las entidades aseguradoras y la canalización del ahorro en España, 1908-1940', Revista española de seguros, 115 (2003), pp. 337-58.

Pons Pons, J., 'The influence of foreign companies in the organization of the Spanish insurance market: diversification and cartelisation 1880-1939', in P. Borscheid and R. Pearson, eds., Internationalisation and globalisation of the insurance industry in the 19th and 20th centuries (Zurich, 2007), pp. 49-65.

Pons Pons, J., 'Multinational enterprises and institutional regulation in the life insurance market in Spain 1880-1935', Business History Review, 82 (2008), pp. 87-114.

Pons Pons, J., 'Las carteras de valores de las compañías de seguros en España (18801940)', Revista de Historia de la Economía y de la Empresa, 3 (2009), pp. 131-50. 
Pons Pons, J., 'A History of insurance companies in Spain until 1936', in Instituto de Ciencias del Seguro, Encuentro internacional sobre la Historia del seguro (Madrid, 2010), pp. 141-74.

Pons Pons, J., 'Las empresas extranjeras en el seguro español ante el aumento del nacionalismo económico (1912-1940)', in J. Pons Pons and M. A. Pons Brías, eds., Investigaciones históricas sobre el seguro español (Madrid, 2010), pp. 191-226.

Pons Pons, J. and Gutiérrez González, P., 'The actuarial practices of British life insurance companies in peripheral countries: the case of Spain (1890-1936)', Enterprise and Society, 17 (2016), pp. 237-64.

Pons Pons, J., 130 años de promesas cumplidas. Grupo Zurich en España (Barcelona, 2015).

Powell, L.S. and Somner, D.W., 'Internal versus external capital markets in the insurance industry: The role of insurance', Journal of Financial Services Research, 31 (2007), pp. 173-88.

Prados de la Escosura, L., El progreso económico de España (1850-2000) (Madrid, 2003).

Prados de la Escosura, L., 'Spain's international position, 1850-1913', Revista de Historia Económica, 28 (2010), pp. 173-215.

Prados de la Escosura, L. and Rosés, J. R., 'Capital accumulation in the long-run: the case of Spain, 1850-2000', Research in Economic History, 27 (2010), pp. 93-152.

Prieto Pérez, E., El reaseguro: función económica (Madrid, 1973).

Rousseau, P.L. and Sylla, R., 'Financial systems, economic growth and globalization', in M.D. Bordo, A.M. Taylor and J.G. Williamson, eds., Globalization in historical perspective (Chicago, 2003), pp. 373-415. 
San Román López, E., 'Las consecuencias pacíficas de la Gran Guerra: la movilización industrial', Hispania, 54 (1994), pp. 611-58.

Sudriá, C., 'Los beneficios de España durante la Gran Guerra. Una aproximación a la balanza de pagos española, 1914-1920', Revista de Historia Económica, 8 (1990), pp. 363-96.

Tortella, G., Caruana, L., García, J. L., Manzano, A., and Pons, J., Historia del seguro en España (Madrid, 2014).

Trebilcock, C., Phoenix Assurance and the Development of British Insurance (Volume 2) (Cambridge, 1998).

Wilkins, M., 'Multinational enterprise in insurance: an historical overview' Business History, 51 (2009), pp. 334-63.

Wooldridge, J.M., Econometric analysis of cross sectional and panel data (Cambridge, 2011). 


\section{APPENDICES}

A.1. Reinsurance determinants in Spanish fire insurance market (1908-1934). Random, fixed and between-effects linear regression models with nationality, exchange rate and firm-specific variables.

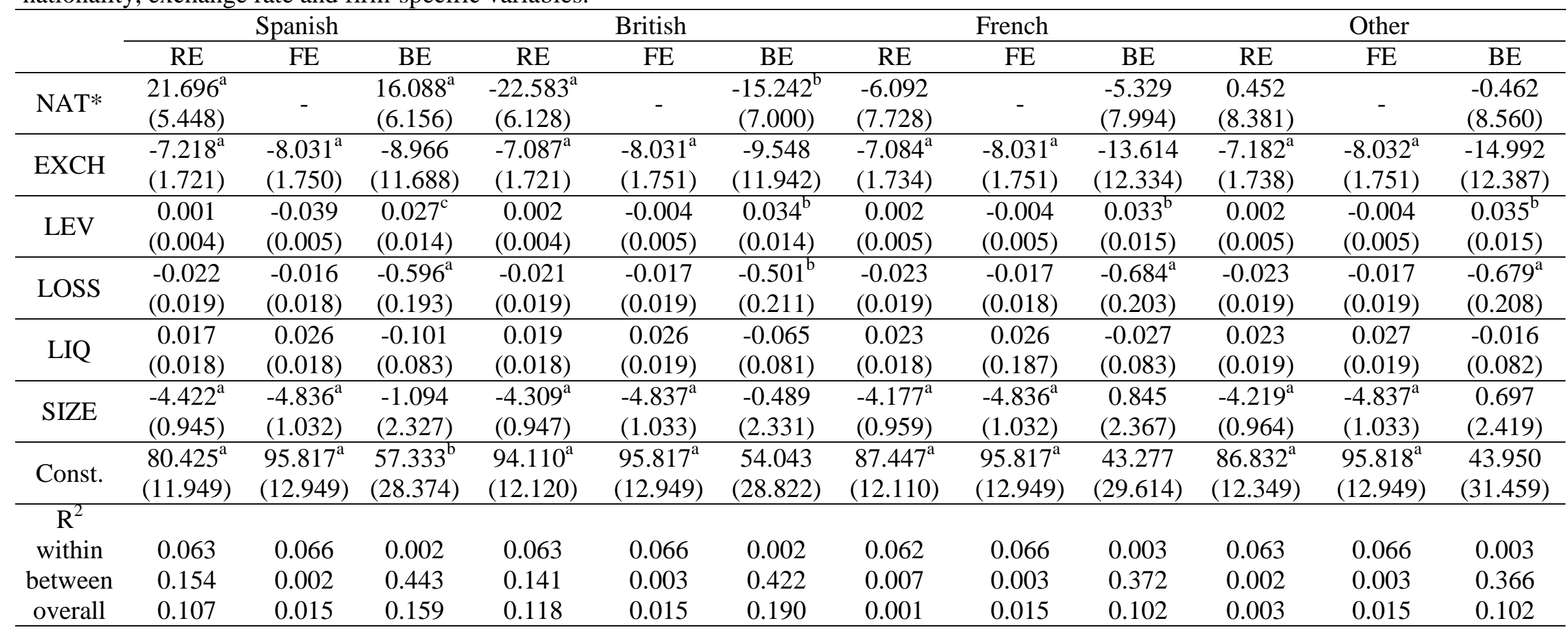

* NATSP for Spanish, NATUK for British, NATFR for French companies and NATOTHER for the rest.

a, b, c Statistically significant at the $1 \%, 5 \%$ and $10 \%$ level.

Note: $\mathrm{EXCH}=$ Official exchange rate of Peseta $/ 100$ French Francs (FF); LEV = Premiums earned $/$ Ongoing-risks reserves, in \%; LOSS = Claims / Premiums earned, in \%; LIQ = Cash + Bank accounts / Premiums earned, in \%; SIZE = Natural logarithm of premiums earned.

Source: AGA (1) 26 - Cajas I-1 to I-141 (Top. 13/31) and AGA (1) 26 - Cajas 11/02131 to 11/02180; Comisaría General de Seguros, Memoria sobre las entidades de seguros que operan en España, Years 1911, 1912, 1913, 1915. 
A.2. T-test on fixed effects term by Spanish nationality.

\begin{tabular}{ccc}
\hline \multirow{2}{*}{ NATSP $=0$} & $\mathrm{~N}$ & Mean (Standard Error) \\
\cline { 2 - 3 } NATSP $=1$ & \multirow{2}{*}{424} & $\begin{array}{l}-7.845 \\
(0.931)\end{array}$ \\
\hline \multirow{2}{*}{ Combined } & \multirow{2}{*}{233} & $\begin{array}{c}14.276 \\
(1.467)\end{array}$ \\
& \multirow{2}{*}{657} & $\begin{array}{l}0.000 \\
(0.895)\end{array}$ \\
\hline \multirow{2}{*}{$\mathrm{t}=-13.3126 \quad \mathrm{P}(\mathrm{T}>\mathrm{t})=0.000$} & \multirow{2}{*}{ Diff. } & $\begin{array}{l}-22.120 \\
(1.662)\end{array}$ \\
\hline
\end{tabular}

Source: AGA (1) 26 - Cajas I-1 to I-141 Top. 13/31 and AGA (1) 26 - Cajas 11/02131 to 11/02180; Comisaría General de Seguros, Memoria sobre las entidades de seguros que operan en España, Years 1911, 1912, 1913, 1915.

A.3. Exchange rates of Spanish Peseta to French Franc and British Pound.

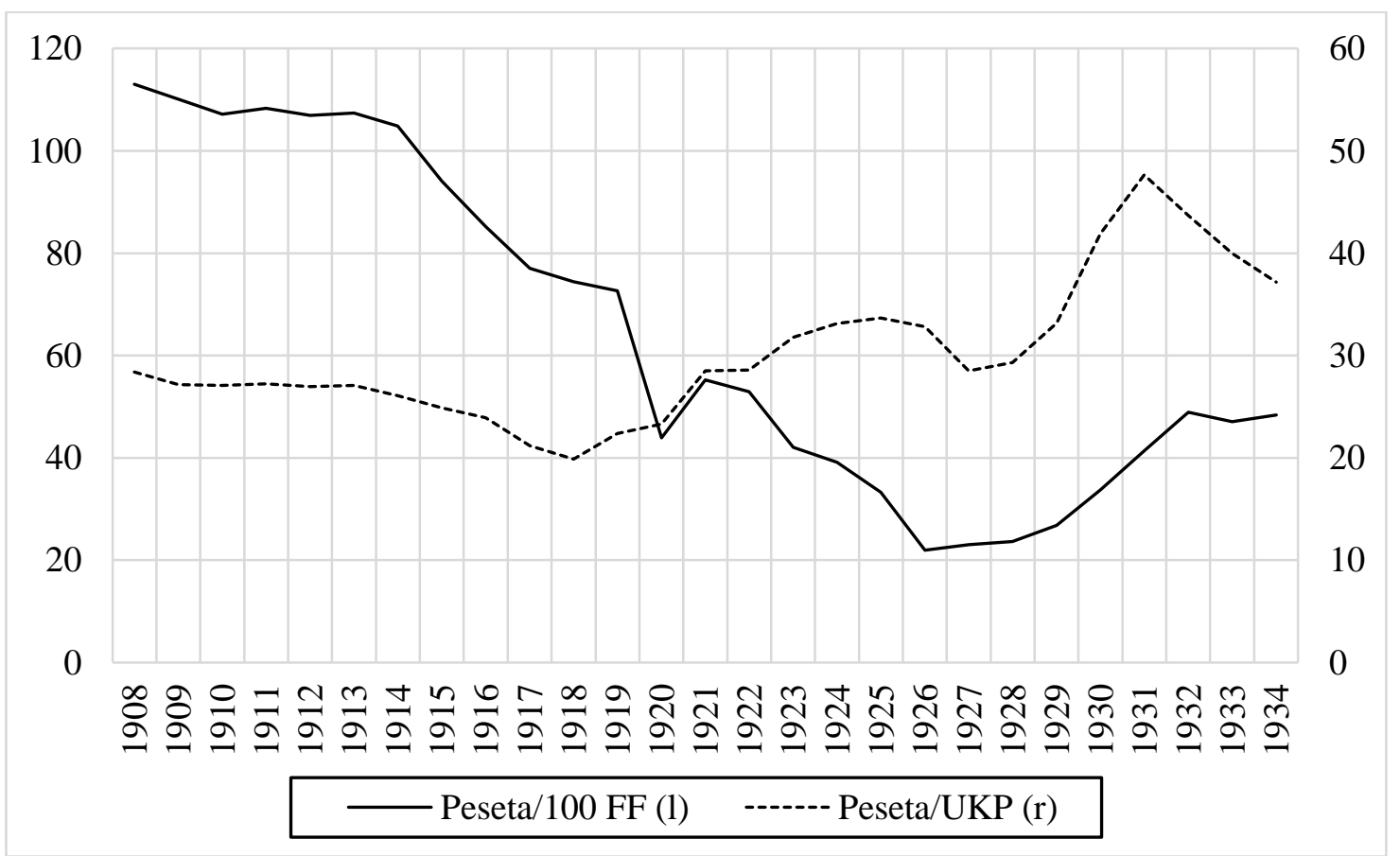

Source: Barciela, Carreras and Tafunell (eds.), Estadísticas históricas de España, 704-5. 
A.4. SIZE as dependent of the rest of firm-specific variables. Random-effects and fixed-effects models.

\begin{tabular}{ccc}
\hline & Fixed-effects model & Random-effects model \\
\cline { 2 - 3 } LEV & $0.0016^{\mathrm{a}}$ & $0.0016^{\mathrm{a}}$ \\
& $(0.0002)$ & $(0.0002)$ \\
\hline \multirow{2}{*}{ LOSS } & $0.0021^{\mathrm{b}}$ & $0.0021^{\mathrm{b}}$ \\
& $(0.0007)$ & $(0.0007)$ \\
\hline \multirow{2}{*}{ LIQ } & $-0.0045^{\mathrm{a}}$ & $-0.0047^{\mathrm{a}}$ \\
& $(0.0007)$ & $(0.0007)$ \\
\hline \multirow{2}{*}{ AGE } & $0.0428^{\mathrm{a}}$ & $0.0418^{\mathrm{a}}$ \\
& $(0.0030)$ & $(0.0028)$ \\
\hline \multirow{2}{*}{ Const. } & $10.6717^{\mathrm{a}}$ & $10.6358^{\mathrm{a}}$ \\
& $(0.1029)$ & $(0.1659)$ \\
R ${ }^{2}$ & & \\
within & 0.427 & 0.426 \\
between & 0.374 & 0.376 \\
overall & 0.376 & 0.378 \\
\hline a,b, Statistically significant at the $1 \%$ and $5 \%$ levels
\end{tabular}

${ }^{\mathrm{a}, \mathrm{b},}$ Statistically significant at the $1 \%$ and $5 \%$ levels.

Note: LEV = Premiums earned / Ongoing-risks reserves, in \%; LOSS = Claims / Premiums earned, in \%; LIQ = Cash + Bank accounts $/$ Premiums earned, in \%.

Source: AGA (1) 26 - Cajas I-1 to I-141 Top. 13/31 and AGA (1) 26 - Cajas 11/02131 to 11/02180; Comisaría General de Seguros, Memoria sobre las entidades de seguros que operan en España, Years 1911, 1912, 1913, 1915. 